\title{
FEASIBILITY STUDY FOR THIXOFORMING NANOSTRUCTURED
}

\section{BAINITIC STEELS}

\author{
L. Rogal $^{1 \text { a,b,c, }}$, W Solano-Alvarez ${ }^{2}$, Z. Szklarz ${ }^{3}$, H.K.D.H. Bhadeshia ${ }^{2}$ \\ ${ }^{1}$ Institute of Metallurgy and Materials Science of the Polish Academy of Sciences, \\ 25 Reymonta St., 30-059 Krakow, Poland \\ e-mail: ${ }^{\mathrm{l}}$ 1.rogal@imim.pl, ${ }^{\mathrm{b}}$ tel.+48 122952801, ${ }^{\mathrm{c}}$ fax +48122952804 \\ ${ }^{2}$ Department of Materials Science and Metallurgy, University of Cambridge, UK \\ ${ }^{3}$ University Science and Technology, 25 Reymonta Str. 30-059 Krakow, Poland
}

Corresponding author: Ł. Rogal, e-mail: 1.rogal@imim.pl, tel.+48 122952801, fax +48 122952804.

Abstract: Super Bainite Steel (0.74\% C, 1.64\% Si, 1.82\% Mn, 1\% Ni, 0.36\% Mo, 0. 21\% Cr, $0.047 \% \mathrm{Al}$ bal. Fe) after cold plastic deformation was used as the starting material for the bainitic treatment preceded by controlled cooling from the thixoforming temperature range. The Differential Scanning Calorimetry was used to determine the amount of the liquid phase fraction vs temperature in the solidus-liquidus range. The steel was heated up to $1430^{\circ} \mathrm{C}$, which corresponded to about $30 \%$ of the liquid fraction. Then it was rapidly cooled in oil at three different temperatures: $240^{\circ} \mathrm{C}, 270^{\circ} \mathrm{C}$ and $300^{\circ} \mathrm{C}$. The samples were then held at those temperatures for $5 \mathrm{~h}$. The microstructure of the samples after treatment at $240^{\circ} \mathrm{C}$ showed globular grains (average size of $115 \mu \mathrm{m}$ ), containing carbide-free bainite as a mixture of ferrite plates with average thickness of $63 \mathrm{~nm}$, and retained austenite plates of thickness 40 nm. Plates of martensite and blocks of austenite were visible in some grain. X-ray studies confirmed the presence of $20.1 \%$ of austenite and $79.9 \%$ of ferrite with martensite. The sample revealed the highest compression strength of $6651 \mathrm{MPa}$, at yield strength of $1780 \mathrm{MPa}$ and compression strain $\varepsilon=38 \%$. With the increase of isothermal treatment temperature up to $270^{\circ} \mathrm{C}$ and $300^{\circ} \mathrm{C}$, yield strength decreased to $1370 \mathrm{MPa}, 1375 \mathrm{MPa}$ and compression strength was $5243 \mathrm{MPa}, 4138 \mathrm{MPa}$, respectively, while plastic strain reached $38.5 \%$ and $25 \%$, respectively. Higher temperature of bainitic treatment led to coarsening of super bainite plates and, in consequence to a decrease in mechanical properties. Initiation of crack propagation was observed at grains. They spread through the globules and eutectic, unlike in thixoformed 
tool steels, in which the crack path runs along the eutectic mixture between the globular grains. Preliminary studies of the corrosion resistance of Super Bainite steels containing carbide-free bainite structure were carried out. Results indicate slightly higher resistance in chlorides environment of the sample isothermally treated at $240^{\circ} \mathrm{C} / 5 \mathrm{~h}$ preceded by controlled cooling from thixoforming temperature range than the sample treated in the conventional way $\left(1000^{\circ} \mathrm{C} / 15 \mathrm{~min} / 240^{\circ} \mathrm{C} / 20 \mathrm{~h}\right)$.

Key words: thixoforming, steel, free carbide bainite, corrosion

\section{Introduction}

New carbide-free bainitic steels called Super Bainitic Steel [1, 2] or NANOBAIN [3] represent a new generation of materials with high strength and toughness. The excellent properties of this steel are mainly due to the formation of a nanostructure consisting of extremely fine, 20-40-nm-thick plates of ferrite and retained austenite, without carbides at ferrite/austenite boundaries [4-7]. These microstructures are achieved through isothermal transformation of high-carbon and high-silicon steels with low martensite start temperature to bainite [8]. The carbide precipitation is suppressed mainly by alloying the steel with about 1.5 wt.\% silicon, which has very low solubility in cementite and greatly retards its growth from austenite [9]. Additionally, the carbon that is rejected from the bainitic ferrite enriches the residual austenite, thereby stabilizing it down to room temperature. Among many methods of bainitic steel production like forging [10], rolling [11] or casting [12], a modern technology such as Semi-Solid Metal processing (SSM) is very promising because it enables to obtain a near-net shape of element in one operation step giving hope to substantially reducing machining and obtaining high integrity structural components $[13,14]$. The application of the novel bainitic steel for semi-solid metal processing is a large technological challenge, due to the specific chemical composition which does not always guarantee proper thermophysical properties of alloy at the solidus-liquidus range. This is caused by the fact that SSM requires a large processing window i.e. wide semi-solid temperature range in the field corresponding to $20-80 \%$ liquid fraction, as well as globular grain shape of the solid phase surrounded by an homogenously distributed liquid phase [15]. When the above criteria are fulfilled, the semi-solid slurry can flow in the thixotropic way [13]. It means that when an alloy is subjected to a high rate shear force, a sudden fall of viscosity occurs. Recently, several types of steels have been selected for SSM such as M2, H13, X210CrW12, X220CrVMo13-4 and HS 6-5-2 [16-19]. Mechanical 
properties of as-processed SSM are poor due to their initial austenitic structure [16]. A heat treatment like tempering or hardening and subsequent tempering was used to improve their mechanical properties [20-24]. A new approach, which enables to obtain the heat treated thixo-cast in a single technological step, consists in combining the thixoforming process followed by controlled cooling to bainitic temperatures including isothermal holding, which was proposed by Rogal et al. in [25]. Such processing allows to produce lower bainite in $100 \mathrm{Cr} 6$ steel with a plate thickness of about $500 \mathrm{~nm}$ and compression strength of $3100 \mathrm{MPa}$ by plastic strain of $32 \%$ [25]. Puttgen et al. [26] conducted an experiment using controlled cooling of $100 \mathrm{Cr} 6$ steel. The authors showed that a maximum hardness $\left(825 \mathrm{HV}_{30}\right)$ and crack resistance $(3,6 \mathrm{~J})$ has been obtained by cooling from $1425^{\circ} \mathrm{C}$ to $850^{\circ} \mathrm{C}$ at a rate of $0.5^{\circ} \mathrm{C} / \mathrm{s}$ followed by cooling in oil, until a martensitic and austenitic structure appeared. Slower cooling rates considerably lowered the degree of $\mathrm{Cr}$ segregation affecting the shift of $M_{s}$ and the decrease of the segregation of carbides [26, 27]. From the various kinds of recently developed novel super bainitic steels [28, 29-36], one of them with high carbon content and low content of alloying elements (such as $\mathrm{Cr}, \mathrm{Mo}, \mathrm{Co}$ ) which are responsible for creating carbides during cooling from semi-solid state has been chosen for the present study. The aim of this study was to determine the conditions for obtaining a bainitic structure in the C0.74Si1.64Mn1.82Mo0.36 Cr0.21 Ni1Fe - balanced wt.\% steel during cooling from the semi-solid range to bainitic temperatures with the use of an isothermal treatment. The kinetic model of bainitic transition proposed by Bhadeshia and Edmunds [37, 38] was used to choose the temperatures of bainitic transformations. The microstructures of samples were analyzed with the use of scanning and transmission electron microscopy.

\section{Experimental procedure}

\subsection{Material}

The Super Bainite Steel was supplied as a bar of $180 \mathrm{~mm}$ in diameter. The chemical composition of the SB steel, measured after homogenization at $1200^{\circ} \mathrm{C}$ for 2 days, was $0.74 \%$ C, $1.64 \% \mathrm{Si}, 1.82 \% \mathrm{Mn}, 1 \% \mathrm{Ni}, 0.36 \% \mathrm{Mo}, 0.21 \% \mathrm{Cr}, 0.047 \%$ Al bal. Fe (wt.\%) using emission optical spectrometer JY 10000 RF JOBIN YVON.

\subsection{Controlled cooling of steel samples}

The semi-solid processing was conducted in an apparatus which is equipped with an inductive heater enabling the heating rate to be steered from $20^{\circ} \mathrm{C}$ to $250^{\circ} \mathrm{C}$ per minute in argon 
atmosphere, followed by cooling in a free medium [25]. The temperature of samples was controlled by 2 thermocouples of type S. In the present study, a sample of superbainite steel (diameter $-30 \mathrm{~mm}$, height $-30 \mathrm{~mm}$ ) was heated at rate $150^{\circ} \mathrm{C} / \mathrm{min}$. After the sample reached the temperature of $1430^{\circ} \mathrm{C}$, which coresponded to about $30 \%$ of liquid phase according to the DSC (Differential Scanning Calorymetry) curve (Fig. 1, point A on dashed line), it was quench in oil to temperatures of 240,270 and $300^{\circ} \mathrm{C}$ and held for $5 \mathrm{~h}$. This material will be referred as SB steel. An average rate of cooling from temperature $1430^{\circ} \mathrm{C}$ to bainitic temperatures was measured to be about $200^{\circ} \mathrm{C} / \mathrm{s}$. After $5 \mathrm{~h}$ the sample was removed from the oil and cooled in the air to room temperature. The samples for the investigation were taken from the cross-section (perpendicular to the axis). Additionally, in order to compare the microstructure and mechanical properties with the state after controlled cooling from the semi-solid state, the supplied steel has been treated in the conventional way; austenitization $1000^{\circ} \mathrm{C} / 15 \mathrm{~min}$ and isothermal treatment at $240^{\circ} \mathrm{C}$ for $20 \mathrm{~h}$. This material will be referred to as SB steel HR.

\subsection{Analysis of microstructure and mechanical properties}

The samples used for optical microscopy were polished and etched in Nital and Mi7Fe $(5 \mathrm{ml}$ of picric acid, $0.5 \%$ alkyl sulfonate sodium, $100 \mathrm{~cm}^{3} \mathrm{H}_{2} \mathrm{O}$ ). The quantitative metallographic analysis was carried out using Leica QUIN image analysis. The calorimetric analysis (Netzsch DSC 404 F1) was applied to measure the solidus-liquidus range and determine the dependence of liquid phase amount as function of temperature. Samples $3 \mathrm{~mm}$ in diameter, and $2 \mathrm{~mm}$ thick were heated in an alumina crucible at the rate of $15^{\circ} \mathrm{C} / \mathrm{min}$ up to $1500^{\circ} \mathrm{C}$ in argon atmosphere. The X-ray phase analysis was performed using a Philips PW 1710 diffractometer with Co-K $\alpha$ filtered radiation and Bruker D8 Advance diffractometer with a position sensitive detector and $\mathrm{Cu}-\mathrm{K} \alpha$ radiation. Scans were performed from 35 to $130^{\circ}$, with a step size of $0.02^{\circ}$, a dwell time of $5 \mathrm{~s}$, and energy levels from 210 to $226 \mathrm{mV}$ to minimize beta peaks. The samples were rotated at $30 \mathrm{rad}^{-1}$ and slits were chosen to restrict the beam depending on the size of the sample. To determine the volume of bainite ferrite, martensite and austenite as well as the concentration of carbon in their content using X-Ray analysis, Rietveld refinement was performed [39], beginning with the fitting of austenite to three of its isolated peaks: 002, 022, and 113. The resulting lattice parameters of the austenite were then used to estimate its carbon concentration [40] and hence, that of any. Since this carbon concentration is inherited $\mathrm{b}$ martensite. The resulting tetragonality of the martensite was then estimated according to [41], permitting the bainitic ferrite to be Reitveld determined without 
any constraints on its lattice parameters. The Reitveld refinement covered the entire spectrum of the diffracted data.

The microstructure and chemical composition were studied using a Scanning Electron Microscope FEI SEM XL30 equipped with an energy dispersive X-ray spectrometer EDAX GEMINI 4000 and a Transmission Electron Microscope (TEM) Philips CM20. The samples for TEM were electro-polished using a Struers Tenupol-5 jet in an electrolyte consisting of $20 \% \mathrm{HClO}_{4}$ and $80 \% \mathrm{CH}_{3} \mathrm{OH}$ at subzero temperatures. Hardness measurements (by Vickers method) were carried out using a Zwick/ZHU $250\left(\mathrm{HV}_{5}\right)$ machine in accordance with (HV) ASTM E 92. The compression test was performed using an INSTRON 3382 machine. The semi-solid cooled steel samples of $5 \times 5 \times 7.5 \mathrm{~mm}$ size were compressed in accordance with the PN-57/H-04320 standard.

\subsection{Experimental procedure of corrosion measurements}

The electrochemical measurements of the Super Bainite steel were conducted in order to characterize its corrosion behavior. The corrosion measurements were performed on two samples: one, which was conventionally treated at $1000^{\circ} \mathrm{C} / 15 \mathrm{~min}$ and $240^{\circ} \mathrm{C} / 20 \mathrm{~h}(\mathrm{SB}$ steel HR) and another, cooled from the semi-solid range: $1430{ }^{\circ} \mathrm{C}$ with isothermal treatment at $240^{\circ} \mathrm{C} / 5 \mathrm{~h}$ (SB steel). The corrosion resistance of specimens was studied in $0.1 \mathrm{M} \mathrm{NaCl}$ aerated water solution at room temperature. Super bainitic steels have limited use due to the lack of weldability, but in strong components such as shafts envisaged for aeroengine applications, corrosion resistance, especially to chlorides, is important. Hence the tests in $0.1 \mathrm{M} \mathrm{NaCl}$ water solution. Each sample was ground with emery papers and polished using diamond pastes down to $1 \mu \mathrm{m}$. After surface preparation specimens were ultrasonically cleaned in ethanol. To analyze the electrochemical behavior, a classical three-electrode system connected with a AUTOLAB PGStat $302 \mathrm{~N}$ potentiostat was used [42, 43]. The counter electrode was a platinum plate, and the reference electrode was $\mathrm{Ag} / \mathrm{AgCl}(3 \mathrm{M} \mathrm{KCl})$ electrode. The corrosion potential at open circuit (OCP) was measured first to analyze the electrochemical response of samples. After the OCP measurements the samples were ground and polished again. Next, potentiodynamic polarization curves (LSV) were plotted starting from $-1.0 \mathrm{~V} / \mathrm{s} \mathrm{Ag} / \mathrm{AgCl}$ to anodic direction at $1 \mathrm{mV} / \mathrm{s}$ potential scan rate to analyze the behavior in the cathodic and anodic domains. 


\section{Results and disccusion}

\subsection{Characterization of starting material}

DSC studies have been carried out in order to determine the solidus-liquidus temperature range. The concentration of carbon, which broadens the temperature of solidus-liquidus range, plays a crucial role in steel thixoforming. A bainitic steel with $0.8 \mathrm{wt} \% \mathrm{C}$ was chosen for experiments according to the chemical composition given in Table 1.

The curves in Figure 1 show heat flow signals for heating and cooling of the SB steel (solid line). The large endothermic effect is connected with the melting process $(165.9 \mathrm{~J} / \mathrm{g})$, which starts at $1350^{\circ} \mathrm{C}$ and ends at $1476^{\circ} \mathrm{C}$. Metallographic (Fig 2a) and X-Ray studies (not presented here), showed that the starting material, supplied in the annealed state, consisted of $12.5 \%-\mathrm{M}_{3} \mathrm{C}$ carbides and $87.5 \%$ of ferrite $(\mathrm{a}=0.2973564 \mathrm{~nm})$. The dissolution of $\mathrm{M}_{3} \mathrm{C}$ carbides took place (above $\mathrm{A}_{\mathrm{Clk}}$ ) during heating to the semi solid-state leading to the enrichment of austenitic grain boundaries in carbon. At around solidus temperature the boundaries start melting, the rate of reaction increases with growing amount of liquid fraction (Fig. 1). During crystallization of SB steel, the endothermic effect ( $137.4 \mathrm{~J} / \mathrm{g}$ ) can be divided in two parts, first one starts at $1468-1408^{\circ} \mathrm{C}$ (solidification of austenitic dendrites) and another at $1408-1345^{\circ} \mathrm{C}$ (crystallization of eutectic mixture). The liquid phase as a function of temperature (dot dash line) was calculated on the basis of the heat flow curve obtained during heating. Controlled cooling from the semi-solid range was carried out at $30 \%$ of liquid phase, which corresponded to the temperature of $1430^{\circ} \mathrm{C}$.

As it was mentioned above, the microstructure of SB steel consisted of partialy spheroidised cementite in the ferrite matrix and perlitic grains, which can be seen in Fig. 2a. The average hardness was $352 \mathrm{HV} \pm 21$. Such a material heated to $1430^{\circ} \mathrm{C}$ (thixoforming temperature) which coresponded to $30 \%$ of liquid phase (according to DSC), showed large primary elongated grains (average size $180 \mu \mathrm{m}$ ), and small ones among them, formed probably from the liquid phase during cooling (Fig. 2b). Such a structure is typical for hot rolled steel, which contains elongated grains that relate to the earlier plastic deformation. In order to obtain a spherical shape of the solid phase at the semi-solid range, required for the thixotropic behaviour of metal suspension, the SB steel was subjected to severe cold plastic deformation (upsetting) with $50 \%$ reduction of height. The microstructure of steel feedstock for thixoforming process is presented in Fig. 2c. It consisted of deformed perlitic grains, in which plates of cementite moved in the direction of deformation. During heating of the material to $1430^{\circ} \mathrm{C}$, which corresponded to about $30 \%$ of liquid phase (according to DSC analysis Fig. 1), 
the thixotropic structure was obtained by the recrystallization and partial remelting process (RAP) [44] (the liquid phase penetrated high angle recristallized grains leading to the sphereoidization of the solid solution [45]). As can be seen in Fig. 2d, the SB steel prepared in that manner revealed the globular microstructure (with an average grain size of $106 \mu \mathrm{m}$ ) surrounded by the eutectic mixture $(21 \%$, calculation based on metallographic analysis from several places). The differences in the estimation of liquid phase amounts observed between the DSC and metallography methods resulted from different heating rates applied. The variations in grain size were caused by the nucleation of a large number of grains (after recrystallization), which started coarsening at temperature close to the solidus. The main factors responsible for the coarsening of structure in the semi-solid range are coalescence and Ostwald ripening mechanism (difference of the curvature radii led to the growth of large grains on expense of smaller ones). It should be noted that dark etched areas visible in the center of the grains are microeutectic particles formed during grain coalescence (marked as arrow in Fig. 2d). This was due to the fact that time time required to distribute the elements was too short to promote segregation. Such phenomena do not occur when globular grains are formed by heterogeneous nucleation and each grain has a different crystalographical orientation so the coalescence process does not take place [46].

The cold deformed SB steel sample, cooled from $1430^{\circ} \mathrm{C}$ in water to room temperature, was used as a model material to determine heat treatment conditions during controlled cooling from the semi-solid state to the bainitic transformation range. For this purpose, detailed characterisation of the microstructure was carried out. The average hardness of samples was $715 \mathrm{HV} \pm 17$, while the microhardness of the microeutectic in the center of the grains (marked with arrow in Fig. 2d), and near grain boundary were $516 \mathrm{HV} \pm 19$ and $734 \mathrm{HV} \pm 35$, respectively. Differences in hardness were connected with the presence of complex phases in the sample due to the occurrence of remelted zones which led to the local segrgation of elements. The X-ray analysis of SB steel confirmed the presence of 16 vol. \% of austenite and $84 \%$ of martensite. A comparatively high amout of $\gamma$-Fe was related to an increased carbon content due to the complete dissolution of carbides. Similar effects were observed in thixoformed $100 \mathrm{Cr} 6$ and $\mathrm{X} 210 \mathrm{CrW} 12$ steels in which the concentration of austenite was $82 \%$ and $33 \%$, respectively $[23,47]$. The differences are due to a lower overall carbon content in the steel in comparison with previously mentioned grades. The study of austenite lattice parameters based on the position of peaks in the X-ray pattern allows the precise determination of carbon concentration in the $\gamma$-Fe phase, which was about $0.8432 \mathrm{wt} . \%$ for 
$0.36088 \mathrm{~nm}$ according to the procedure included in [48]. Additionally, study based on thermodynamic calculations was conducted to estimate characteristic temperatures during continuous cooling from $1430^{\circ} \mathrm{C}$ (which corresponded to $30 \%$ liquid fraction according to DSC). For that purpose, the $T_{0}{ }^{\prime}$ (which was defined by the locus of the points $G^{\gamma}=G^{\alpha}+k$ ) and the $\mathrm{Ae}_{3}(\gamma / \gamma+\alpha$ transus temperature curve) temperatures were determined in accordance with Bhadeshia and Edmonds models [49]. The bainite forms at temperature $\mathrm{T}$ which is $\mathrm{M}_{\mathrm{S}}<$ $\mathrm{T}<\mathrm{T}_{0}[50,51]$. The nucleation limited bainite start temperature $\left(B_{S}\right)$ was assessed at about $230^{\circ} \mathrm{C}$, while growth limited temperature at about $311^{\circ} \mathrm{C}$. The dilatometry study enabled the estimation of $M s$ temperature, which was about $131^{\circ} \mathrm{C}$. However, it should be noted that the martensite start temperature of the sample treated in the SSM range influenced various additional factors. For example, Puttgen et al. [27, 28], using a computer simulation based on the DICTRA software, claimed that the increase of cooling rate from $0,5^{\circ} \mathrm{C} / \mathrm{s}$ to $300^{\circ} \mathrm{C} / \mathrm{s}$ of $100 \mathrm{Cr} 6$ steel from the semi-solid range to room temperature should cause a greater segregation of $\mathrm{Cr}, \mathrm{S}, \mathrm{Si}$ at grain boundaries. In consequence it led to a change in the $M \mathrm{~s}$ temperature.

It is well known [28], that the bainitic transformation strongly depends on carbon content in the austenite [52]. The heterogeneity at the intersection of grains and local segregation of carbon in the thixo-formed steel may cause the appearance of various structures such as tempered martensite as well as a large area of non-transformed austenite [23, 25]. Taking into account the above factors, several experiments were designed, which consisted in isothermally heat-treating SB steel in a wide temperature range. Three temperature values for 5-hour-isothermal soaking were selected: 240,270 and $300^{\circ} \mathrm{C}$, which were close to the $B s$ temperature determined from the thermodynamic calculation. Caballero et al. [53] conducted a heat treatment of a steel with similar chemical composition (with $\mathrm{Cr}$ instead of Ni). It consisted of austenitization at $1000^{\circ} \mathrm{C} / 15 \mathrm{~min}$ and isothermal treatment in range $125-350^{\circ} \mathrm{C}$, for period of time from 120 days to several hours. As a result, plates of carbide free bainite of the thickness of 20 to tens of nanometers were obtained. It was observed that structure refinement appeared when the temperature of transformation decreased and soaking time increased at the same time. Bhadeshia [53, 54] and Song [55] observed micro-size lower bainite with precipitates of transitional carbides in $100 \mathrm{Cr} 6$ steel austenitized at $850^{\circ} \mathrm{C} / 30 \mathrm{~min}$ and then cooled with the isothermal treatment at temperatures from 230 to $260^{\circ} \mathrm{C}$, after $2-10 \mathrm{~h}$. As can be seen, depending on chemical composition and heat treatment conditions of steels, it is possible to obtain various morphology of bainite. In the present study a new SB steel, originally designed to obtain free carbide nano-bainite structure by typical heat treatment, has 
been considered as a potential material for semi-solid metal processing. It is a new approach, aiming at finding an alternative process of shaping modern steels.

\subsection{Bainitic treatments of SB steel cooled from semi-solid temperature range}

The metallographic study of the sample after cooling from $1430^{\circ} \mathrm{C}$ to $240^{\circ} \mathrm{C}$, followed by annealing for $5 \mathrm{~h}$, showed that it consisted of globular grains of $115 \mu \mathrm{m}$ average size, surrounded by the secondary phase. The average hardness in the volume of the sample was $689 \mathrm{HV} \pm 23$. Microhardness near grain boundaries was $448 \mathrm{HV} \pm 29$, which suggested the presence of untransformed residual austenite. It probably formed in places where remelted zone appeared, leading to enrichment of $\gamma$-Fe in carbon in consequence of its stabilization. The presence of remelted areas inside the grains is a common phenomenon in thixoformed samples for which feedstock has been prepared with the use of SIMA or RAP methods [56]. In the $100 \mathrm{Cr} 6$ steel thixoformed at $1425^{\circ} \mathrm{C} / 235^{\circ} \mathrm{C} / 5 \mathrm{~h}$, hardness near grain boundaries was 758 $\mathrm{HV}$, due to the presence of tempered martensite and $\mathrm{M}_{7} \mathrm{C}_{3}$ carbides, while in the center of the grains it was $679 \mathrm{HV} \pm 8$ (lower bainite) [25]. In the present study the lower hardness near boundaries was a result of the lack of hard and brittle carbides, as well as the presence of austenite and bainite instead. It should be noted that the studied steel contained trace amounts of carbide forming elements such as Mo. Therefore, when the liquid phase, responsible for the segregation of elements (in the semi-solid state), appeared, plastic austenitic phase was formed near grain boundary after isothermal cooling, which can lead to an increase of steel toughness after SSM. The microstructure analysis presented in Figure $3 \mathrm{a}$ and $\mathrm{b}$ showed the images of globular grains using light and scanning microscopy, respectively. Fine bainite sheaves (of $669 \mathrm{HV} \pm 32$ ) with islands of un-transformed austenite (Fig. 3a and b) can be seen inside the grains. Plates of martensite with hardness of $754 \mathrm{HV} \pm 23$ are visible in some grain areas. Detailed identification of structure morphology is not easy to carry out using optical microscopy, therefore studies of microstructures using higher magnification have been performed. Figure $4 \mathrm{a}$ and $\mathrm{b}$ show TEM micrographs of the sample after isothermal treatment at $240{ }^{\circ} \mathrm{C}$ for $5 \mathrm{~h}$, obtained from the same place, but different orientations (the variations in the inclination angle were about $15^{\circ}$ ), which allowed the confirmation of the presence of two separate phases. TEM confirmed the presence of carbide free bainite, which consisted of an intimate mixture of carbon supersaturated ferrite plates (marked as $\alpha_{b}$ in Fig 4. a and b) with the average thickness of $63 \mathrm{~nm}$, and the retained austenite (marked as $\gamma^{\prime}$ in Fig $4 \mathrm{a}$ and b) with the thickness of $40 \mathrm{~nm}$. Electron diffraction (Fig. $4 \mathrm{~b}$ - inserted pattern) from the dark plates marked with a circle in Fig 4b, allowed identification of the phase which gave strong 
reflections. Based on the distances between the reflections and angles between them, $\alpha_{b}$ was identified at [-111] zone axis. It should also be noted that the bainitic ferrite-austenite interface was free from any precipitates. Additionally, the structure obtained, as illustrated in Fig $4 \mathrm{a}, 4 \mathrm{~b}$ was close to the structure of the SB steel obtained in a conventional way, because their length scale of the plates and morphology were comparable [57, 31]. Fig. 4c also shows a TEM-BF micrograph of another area of globular grains, confirming the presence of martensite. The SAEDP (Selected Area Electron Diffraction) from the plates shows strong reflections at 1-10 and 10-1 from the $\alpha^{\prime}$-Fe with [111] zone axis. It should be noted that the diffraction pattern at the $<111>$ zone axis cannot reveal the twins because of its symmetry, however TEM-BF (Fig. 4c) shows a morphology characteristic for twins in martensite. The presence of martensite confirmed that the isothermal treatment did not produce a fully stable austenitic structure. In the bulk form, it transformed during cooling into martensite at around $130-140^{\circ} \mathrm{C}$. The X-ray studies confirmed the presence of $20.1 \%$ of austenite and $79.9 \%$ of ferrite $(65.9 \%)$ and martensite $(14 \%)$. The carbon concentration in the $\gamma$ phase was $0.85 \%$. Caballero at al. [58] noticed that in a SB steel with a similar chemical composition, the carbon content in austenite was close to the overall concentration after short-time isothermal holding. However, with the increasing time of soaking at $200^{\circ} \mathrm{C}$ the carbon content in austenite gradually exceeded the overall amount [58]. With the increase of temperature during isothermal treatment, the carbon content in austenite increased with a simultaneous decrease of ferrite content [59]. The higher temperature speeded up the reaction time [28]. Additionally, as can be seen in Figure 4d, the retained austenite trapped between the slender plates of ferrite formed a nano-film of $15 \mathrm{~nm}$ thickness. Such a phenomenon probably took place because the nucleation of other plates occurred alongside existing plates, inside a larger sheaf. A similar effect was observed in [3], where the $\gamma$ phase formed a much thinner film inside the structure plates. The differences in film thickness are probably connected with a higher temperature of the isothermal treatment applied in the present study.

In the next stage of the study a detailed characterization of SB steel sample after controlled cooling from $1430^{\circ} \mathrm{C}$ to $270^{\circ} \mathrm{C} / 5 \mathrm{~h}$ was conducted. The average grain size $122 \mu \mathrm{m}$ was nearly the same as for the sample treated at $240^{\circ} \mathrm{C} / 5 \mathrm{~h}$ since the coarsening effect of globular grains was visible at temperatures above $\mathrm{Ac}_{3}$. However, when comparing grain size of SB steel after SSM with the size after a typical heat treatment [59], large differences in microstructure were seen due to significant variations in temperature of the process. Thus, for the SB steel after the standard treatment, consisting of austenitization at $1000^{\circ} \mathrm{C} / 15 \mathrm{~min} / 200^{\circ} \mathrm{C} / 144 \mathrm{~h}$, the size of grain was in the range $20-30 \mu \mathrm{m}$ [59]. According to Bhadeshia [28] grain size does not affect 
bainitic transformation. It should be noted that after the conventional treatment the structure was nearly homogenous in volume, while in the SSM sample, there was segregation at grain boundaries. However, this negative effect can be eliminated by isothermal treatment, leading to the formation of a plastic stable austenitic structure instead of martensite and carbides like in the case of the 100Cr6 thixoformed sample [23, 25].

Figures $3 \mathrm{c}$ and $\mathrm{d}$ present microstructures of the sample treated at $270^{\circ} \mathrm{C} / 5 \mathrm{~h}$. In comparison with the state after $240^{\circ} \mathrm{C} / 5 \mathrm{~h}$ treatment, significant changes inside the grains are visible. The microstructure consists of larger bainite sheaves and coarse plates of tempered martensite marked with arrows. Additionally, blocky of austenite regions can be seen among them. The microhardness of bainitic structure (sheaves) was $695 \mathrm{HV} \pm 33$, while near the grain boundary, where the secondary phase formed, it was $545 \mathrm{HV} \pm 17$ at average sample hardness of $582 \pm 21$ The X-ray analysis confirmed the presence of $28 \%$ of residual austenite and $72 \%$ of martensite (28\%) and bainite (44\%). The higher content of residual austenite in comparison with $240^{\circ} \mathrm{C} / 5 \mathrm{~h}$ is caused by a higher temperature of isothermal treatment. The $\gamma$ phase amount was expected to increase at higher transformation temperatures as can be also seen in [59]. The carbon concentration in the residual austenite, determined on the basis of X-ray analysis (using Rietveld refinement in High Score software), was 1.01\%wt. and was higher than after the $240^{\circ} \mathrm{C} / 5 \mathrm{~h}$ processing. Figure 5 shows transmission electron micrographs for samples cooled from $1430^{\circ} \mathrm{C}$ to $270^{\circ} \mathrm{C} / 5 \mathrm{~h}$. There is a fine mixture of bainitic ferrite (apparent thickness about $230 \mathrm{~nm}$ ), surrounded by thin films of austenite (apparent thickness about 40 $\mathrm{nm})$. The thicknesses reported here are larger than in [59] but the transformation temperature here is greater at $270^{\circ} \mathrm{C}$. The observed coarsening of $270^{\circ} \mathrm{C} / 5 \mathrm{~h}$ structure in relation to that of $240^{\circ} \mathrm{C} / 5 \mathrm{~h}$ was mainly the consequence of the high carbon content in austenite and the higher transformation temperature.

The electron diffraction from another grain area, marked with a circle in Fig. 5b, allowed to identify the crystallographic structure of dark plates, which gave weak reflections, apart from strong ones from the matrix. Based on the distances between the reflexes and angles between them, $\eta-\mathrm{Fe}_{2} \mathrm{C}$ carbide was identified to have the orthorhombic lattice at [-110] zone axis and supersaturated bainite ferrite with [010] zone axis. As can be seen in Fig. 5ab, it was confirmed that inside the $\alpha_{b}$ lath, the precipitation of transitional carbide occurred as a secondary process during the bainitic reaction [31]. An unexpected phenomenon of carbide formation in free carbide bainite can be explained using SEM-EDS results (not presented here), which shows that inhomogeneous distribution of elements occurs near grain boundary. In this case, studies confirmed local depletion of Si. As it is well known, silicon content has 
an influence on the suppression of carbides [28]. During TEM studies such areas were probably observed.

In the steel with a similar chemical composition, such extensive aging at $200^{\circ} \mathrm{C}$ for 14 days led to the precipitation of few cementite particles, $20 \mathrm{~nm}$ wide and $175 \mathrm{~nm}$ long [59]. Carbon atom mapping conducted using Atom Probe Tomography (APT) showed the carbon segregation across a cementite particle in the nanostructure bainitic steel [31]. The SAEDP from another plate confirmed the presence of $\alpha_{b}$ with [0-11] zone axis. Lack of additional reflexes from carbides can be caused by a thick area of TEM foil. Additionally, Fig. 6 shows TEM-BF micrograph of a different sample part, confirming the presence of microstructure with martensite morphology. A strong contrast between plates enabled the measurement of their thickness, which was in the range from 10-50 $\mathrm{nm}$. The SAEDP from the central part of the micrograph shows strong reflexes 112 and 200 from the $\alpha^{\prime}$ with zone axis [0-21] as well as less visible ones from $\eta$-carbides with orthorhombic lattice at [101] zone axis. This kind of precipitations is typical for the $100 \mathrm{Cr} 6$ steel after austenitization $\left(850^{\circ} \mathrm{C} / 0.5 \mathrm{~h}\right)$ and tempering at $150^{\circ} \mathrm{C}$ for $2 \mathrm{~h}[54,60]$. Similar precipitates were present in the $100 \mathrm{Cr} 6$ steel cooled from semi-solid range to $135^{\circ} \mathrm{C} / 5 \mathrm{~h} \mathrm{[25]} \mathrm{as} \mathrm{well} \mathrm{as} \mathrm{after} \mathrm{tempering} \mathrm{[23].} \mathrm{The} \mathrm{martensite} \mathrm{obtained} \mathrm{in}$ the present study formed probably after isothermal transformation to bainite, and the transitional carbides formed during air cooling from transformation temperatures to room temperature via auto-tempering. However, due to the segregation of carbon, the existence of places (mainly near grain boundary) where martensite start temperature is higher than in the rest of the sample is likely.

The microstructures of SB steel heated to $1430^{\circ} \mathrm{C}$ and cooled to $300^{\circ} \mathrm{C} / 5 \mathrm{~h}$ obtained using optical microscopy and scanning electron microscopy are presented in Fig. 3e and f. Coarse bainite sheaves with tempered martensite plates (marked as arrow in Fig. 3e and f) and an island of un-transformed residual austenite (marked as dashed ring in Fig. 3e) are visible. The "blocks" of retained austenite are not desirable since they are likely to cause crack initiation as a result of formation of brittle martensite during deformation [61]. The X-ray analysis confirmed the presence of $27.9 \%-\gamma$ with $0.94 \%$ carbon concentration and $72.1 \%$ of $\alpha_{b}$ and $\alpha$ '. The average hardness of the sample was $507 \mathrm{HV} \pm 34$, while the microhardness of secondary phase area (grain boundary) reached $518 \mathrm{HV} \pm 12$. The differences in comparison with 240 and $270{ }^{\circ} \mathrm{C} / 5 \mathrm{~h}$ values of microhardness resulted from a coarser structure and higher austenite volume. TEM-BF micrographs from globular grains of SB steel after treatment at $300^{\circ} \mathrm{C} / 5 \mathrm{~h}$ are presented in Figure $7 \mathrm{a}$ and $\mathrm{b}$. Bright field images were obtained at different Bragg conditions, which enabled confirming the presence of two separate phases. The 
SAEDPs presented in Fig. 7c and d, correspond to places of analysis marked with rings in Fig. $7 \mathrm{a}$ and $\mathrm{b}$. That allowed identification of the $\alpha_{\mathrm{b}}$ with [1-11] zone axis and average thickness $294 \mathrm{~nm}$ and the $\gamma$ with orientation [-110] and average thickness $121 \mathrm{~nm}$. Coarsening of bainitic structures with increasing temperature of transformation is consistent with the study included in $[25,59]$. Another TEM-BF image presents a structure with the morphology typical for martensite (Fig. 8). Selected area diffraction pattern from the central part of micrograph shows strong reflexes from the $\alpha$ '-Fe phase at [1-11] zone axis. Lack of additional reflexes from transitional carbides suggests that such a type of martensite formed directly during cooling from $300^{\circ} \mathrm{C}$. However, it should be noted that the sample after that kind of treatment $\left(300^{\circ} \mathrm{C} / 5 \mathrm{~h}\right)$ revealed the highest content of coarse tempered martensite. Another $\mathrm{BF}$ image from the area of extremely large super bainite structure is presented in Figure 9a. The SAEDP analysis (Fig. $9 \mathrm{~b}$ and c) confirmed the presence of $\alpha_{b}$ with [110] orientation and $\gamma$ at zone axis [110]. High density of dislocations as well as slip bands are present inside the austenite structure. In the supersaturated $\alpha_{b}$ plates, changes in contrast helped to see additional small film of retained austenite (inclined $45^{\circ}$ to the $\alpha_{b}$ lath), which was also observed in the structure after the treatment at $270^{\circ} \mathrm{C} / 5 \mathrm{~h}$. A large number of defects in the $\gamma$ were connected with its deformation. High dislocation density in the super bainite ferrite resulted in a huge supersaturation of carbon in the ferrite after transformation [28, 59].

\subsection{Analysis of mechanical properties}

The highest strength of SB steel after a typical heat treatment can be achieved when martensite, bainite and austenite appear as a mixture $[49,62]$. Such a combination of phases can be stronger than each of the individual phases [49]. The main advantage of the bainitic transformation from the mechanical point of view relies in achieving sufficient enrichment in carbon at the austenite which will be stable enough to be retained in the microstructure, but prone to transformation upon deformation. The ability of bainitic steels to produce retained austenite in the final microstructure has allowed a greater manipulation of the resultant mechanical properties [61].

Fig. 10 shows the compression test results of the SB steel samples; directly after cooling from $1430^{\circ} \mathrm{C}$ to water (fine dot line) and to oil at a temperature of $100^{\circ} \mathrm{C}$ (dashed line) as well as after isothermal treatments at $240^{\circ} \mathrm{C}$ (dot-dash line), $270^{\circ} \mathrm{C}$ (solid line) and $300{ }^{\circ} \mathrm{C}$ (double dot and dashed line) for a soaking time of $5 \mathrm{~h}$. Additionally, precise values of compression strength analysis are presented in Table 2. It can be seen that the maximum compression strength, $6651 \mathrm{MPa}$, was achieved by the sample after isothermal treatment at $240^{\circ} \mathrm{C} / 5 \mathrm{~h}$, 
along with a yield strength of $1780 \mathrm{MPa}$ and a compression strain $\varepsilon=38 \%$. At that stage, the sample microstructure consisted of globular grains, inside which there was a mixture of nano plates of bainite, martensite and a relatively low volume of retained austenite. Such a combination of phases gives optimum mechanical properties of SB steel samples after bainitic treatment preceded by heating to semi-solid state. It should be noted that the microstructure after $1430^{\circ} \mathrm{C} / 240^{\circ} \mathrm{C} / 5 \mathrm{~h}$ had the closest morphology to the super bainite presented in [28]. However, it is significant that it did not occur in the whole volume of the sample due to the segregation effect induced by the existence of a liquid fraction at $1430^{\circ} \mathrm{C}$. In the C0.8Si1.6Mn1.9Cr1.2Mo0.3 steel treated with conventional method $\left(1000^{\circ} \mathrm{C} / 15 \mathrm{~min} / 190^{\circ} \mathrm{C} / 2\right.$ weeks $)$, super bainite with a plate width of some $50 \mathrm{~nm}$ was obtained. It had the following mechanical properties: hardness $650 \mathrm{HV}$, compression strength 2400 MPa by YS $1970 \mathrm{MPa}$ and plastic strain of 15\% (Tab. 2) [53]. Higher compression strength and ductility in the SB steel cooled from the semi-solid range were probably caused by more stable retained austenite present in the grains, which could not transform into brittle martensite. In addition, boundaries of large globular grains played a crucial role in mechanical properties. As it was confirmed by microscopy, mechanically stable and plastic austenite occurred among the boundaries. It was also enriched in carbon, which could lead to its stability and in consequence might give features allowing the accumulation of cracks and stress. It is believed that this factor could be responsible for the increase in fracture toughness. A higher hardness in comparison with the conventional treatment was most likely caused by the presence of an increased content of martensite after treatment at $1430^{\circ} \mathrm{C} / 240^{\circ} \mathrm{C} / 5 \mathrm{~h}$ (Fig. 11). In the $100 \mathrm{Cr} 6$ steel treated at $1425^{\circ} \mathrm{C} / 235^{\circ} \mathrm{C} / 5 \mathrm{~h}$, lower bainite, martensite and austenite were obtained inside the grains [25]. However, among globules, a mixture of carbides and brittle martensite occurred, which led to crack formation around grains and low compression strength $[23,25]$. It should be noted, that such a feature was not observed in the present study. In order to determine the influence of strain on the hardening effect (during deformation) the hardness of the sample after compression test was studied. In the $1430^{\circ} \mathrm{C} / 240^{\circ} \mathrm{C} / 5 \mathrm{~h} \mathrm{SB}$ steel strained 38\%, which corresponded to $6651 \mathrm{MPa}$, hardness increased up to $780 \mathrm{HV} \pm 20$ (Fig. 11). The microstructure consisted of grains deformed in a perpendicular direction to the strain, with numerous cracks. The strong hardening effect due to the strain induced transformation of austenite into martensite has been confirmed by X-ray analysis (Fig. 12). The diffraction pattern showed a nearly complete phase transformation $\gamma \rightarrow \alpha$ '. Such a phenomenon was observed in bainitic steels $[28,53]$. A similar hardening effect in the deformed 304 austenitic 
stainless steel [63] and in a high manganese steel [64] was reported to have resulted from the formation of twins and $\varepsilon$-martensite.

With the increase in isothermal treatment temperature up to $270^{\circ} \mathrm{C}$ and $300^{\circ} \mathrm{C}$, the yield strength and compression strength decreased to $1370 \mathrm{MPa}, 1375 \mathrm{MPa}$ and $5243 \mathrm{MPa}, 4138$ $\mathrm{MPa}$, respectively, while plastic strain was $38.5 \%$ and $25 \%$, respectively. Higher temperature of bainitic treatment led to coarsening of super bainite plates and tempering of martensite (auto- tempering effect during cooling from higher temperature of bainitic transformation) in consequence decreased the mechanical properties. The lower yield strength is mainly due to higher volume of austenite. It is consistent with the studies showed in [59]. The hardening effect was also observed in the SB steel treated at $1430^{\circ} \mathrm{C} / 270^{\circ} \mathrm{C} / 5 \mathrm{~h}$ and $1430^{\circ} \mathrm{C} / 300^{\circ} \mathrm{C} / 5 \mathrm{~h}$, next strained to $38 \%$ and $25 \%$. That resulted in the increase of hardness to about 137 and 98 $\mathrm{HV}$, respectively. In order to characterize precisely the mechanism of deformation a further study of microstructure was carried out. Fig. 13a and b presents the microstructure of SB sample processed at $1430^{\circ} \mathrm{C} / 270^{\circ} \mathrm{C} / 5 \mathrm{~h}$ and compressed at the stress of $5.2 \mathrm{GPa}$. The optical image (Fig. 13a, etched with Nital) showed deformed grains containing cracks, which ran throughout the globules and eutectic (secondary phase), contrary to those in the thixoformed $100 \mathrm{Cr} 6$ and $\mathrm{X} 210 \mathrm{CrW} 12$ steels, where crack path ran along the eutectic mixture between the globular grains [25, 47]. The scratch propagation is marked as double arrow, while the probable places, in which cracking was initiated has been marked as singe arrow. No starting cracks occurred within the eutectic mixture existing among the grains. SEM (Fig. 13b) enabled to show the frequent deformed bainite (marked with a circle in Fig. 13b) and stress transformed martensite from austenite (marked with rectangular, Fig 13b). It was observed that cracks were initiated at blocky untransformed austenite, facilitating transformation induced plasticity (marked with arrow, Fig 13b). The TEM studies showed the presence of a large number of defects in the structure and deformed super bainite plates (Fig. 13c). In addition, compression test analysis were conducted for the SB steel cooled from $1430^{\circ} \mathrm{C}$ to water either oil of temperature 20 and $100^{\circ} \mathrm{C}$, respectively without isothermal treatment. Such a procedure enabled obtaining the typical martensitic structure with residual austenite.

\subsection{Analysis of corrosion resistance}

In order to determine the influence of two kinds of heat treatments, which enable to obtain a carbide free bainitic structure on the corrosion behavior of the newly designed steel, the corrosion potential (Open Circuit Potential - OCP) and polarization curves (Linear Sweep Voltammetry - LSV) were performed in $0.1 \mathrm{M} \mathrm{NaCl}$ solution. 
As it is shown in Figure $14 \mathrm{a}$ the corrosion potential for both samples; SB steel $\left(1430^{\circ} \mathrm{C} / 240^{\circ} \mathrm{C} / 5 \mathrm{~h}\right.$; dot line $)$ and SB steel HR $\left(1000^{\circ} \mathrm{C} / 240^{\circ} \mathrm{C} / 20 \mathrm{~h}\right.$; solid line $)$ decreased with exposure time which, was related to active corrosion in the $0.1 \mathrm{M} \mathrm{NaCl}$ electrolyte. The value of the OCP of the SB steel HR sample was $-630 \mathrm{mV}$ vs. $\mathrm{Ag} / \mathrm{AgCl}$ after 4 hours of immersion in $0.1 \mathrm{M} \mathrm{NaCl}$ water solution. A higher value of OCP after 4 hour-immersion was recorded for the $\mathrm{SB}$ steel $(-612 \mathrm{mV}$ vs. $\mathrm{Ag} / \mathrm{AgCl})$. After $20 \mathrm{~h}$ immersion in the solution, the corrosion potentials for SB steel HR and SB steel achieved respectively: $-630 \mathrm{mV}$ and $-620 \mathrm{mV}$. The corrosion potentials for both samples after $20 \mathrm{~h}$ immersion were stable.

Figure $14 \mathrm{~b}$ presents the potentiodynamic polarization curves plotted for both samples from cathodic to anodic domain. The studies confirmed the previous OCP measurements. As can be seen the corrosion potential value of the SB steel (dot line) is slightly higher compared with the SB-steel HR (solid line). Moreover, the potential of anodic dissolution is also shifted towards higher values for the isothermally treated sample preceded by cooling from the semisolid range.

It is well known that different types of modifications such as heat treatment or process production of a given metallic alloy can affect the microstructure and change the corrosion properties [65-67]. For example, the nano bainitic structure shows slightly better corrosion resistance than martensite in the steel with the same chemical composition [68].

The results presented above do not show significant difference in electrochemical response between the two SB steel samples. The similar corrosion behavior results from having almost the same phase composition. Both SB steel HR and SB steel are prone to corrosion in $0.1 \mathrm{M}$ $\mathrm{NaCl}$ environment and undergo active dissolution, which is clearly seen in the corrosion potential plot (Fig. 14a) and polarization curves (there is no passivation range, Fig. 14b). However, the electrochemical analysis suggests that the steel treated at $1430^{\circ} \mathrm{C} / 240^{\circ} \mathrm{C} / 5 \mathrm{~h}$ marginally improved its corrosion resistance in chlorides. Slightly more noble values of the corrosion potential both in OCP and LSV measurements were observed for the SB steel (dot line). The slower decline corresponds also to an inflection observed at the anodic part of the LSV curve obtained for the SB steel. Such a behavior of the curve suggests slight blocking of the sample surface by the layer of corrosion products. Therefore, additional surface observations and analysis of the corrosion products are needed to explain such delicate differences in the corrosion mechanisms of these two samples. 


\section{Conclusions}

1. The cold plastic deformation of SB steel consisting of upsetting with $50 \%$ reduction turned out to be a good way of feedstock preparation for thixoforming process. Sample microstructure after cooling to $1430^{\circ} \mathrm{C}$, which corresponded to $30 \%$ liquid fraction consisted of globular grains (with average grain size of $106 \mu \mathrm{m}$ ) surrounded by eutectic mixture.

2. The SB steel after cooling from $1425^{\circ} \mathrm{C}$ to $230^{\circ} \mathrm{C}$ and held at that temperature for $5 \mathrm{~h}$ contained carbide free bainite which consisted of an intimate mixture of carbon supersaturated ferrite plates with an average thickness of $63 \mathrm{~nm}$ and retained austenite with thickness of 40 nm. X-ray studies confirmed presence of $20.1 \%$ of austenite and $79.9 \%$ of ferrite and martensite. The average hardness of samples was $689 \mathrm{HV} \pm 23$, while compression strength attained was $6651 \mathrm{MPa}$ at plastic strain 38\%.

3. The isothermal treatment of sample at $270^{\circ} \mathrm{C} / 5 \mathrm{~h}$ revealed fine-scale mixture of super saturated ferrite (plate thickness $229 \mathrm{~nm}$ ) surrounded by a thin film of austenite $(43 \mathrm{~nm})$. Inside $\alpha$-bainite plate, $\eta$ - $\mathrm{Fe}_{2} \mathrm{C}$ carbide was identified to have orthorhombic lattice. Average hardness of samples decreased to $582 \mathrm{HV} \pm 21$, while compression strength reached $5243 \mathrm{MPa}$ at plastic strain $38.5 \%$.

4. The microstructure of samples after cooling from $1430^{\circ} \mathrm{C}$ and isothermal treatment at $300^{\circ} \mathrm{C}$ for $5 \mathrm{~h}$ consisted of globular grains, inside which the coarse super bainite structure was present. The average hardness was $507 \mathrm{HV} \pm 34$, while compression strength decreased to 4138 MPa.

5. Electrochemical studies performed in order to determine corrosion resistance in chloride environment revealed a small difference in the corrosion behavior between Super Bainite steels treated at $1430^{\circ} \mathrm{C} / 240^{\circ} \mathrm{C} / 5 \mathrm{~h}$ and $1000^{\circ} \mathrm{C} / 240^{\circ} \mathrm{C} / 20 \mathrm{~h}$ (standard heat treatment).

\section{Acknowledgments}

The research was supported by Polish science financial resources Applied Research Programme of the National Centre for Research and Development in Poland; "Developing a technology of producing complex elements by steel thixoforming”PBS1/B5/22/2013.

\section{Reference:}

[1] J.A. Mawella, F.G. Caballero y H.K.D.H. Bhadeshia "Improved Bainitic Steel, patent US6884306.

[2] H.K.D.H. Bhadeshia, P. Brown, C. Garcia-Mateo, Bainite steel and methods of manufacture thereof, patent US8,956,470. 
[3] F. G. Caballero, C. Garcia-Mateo, M. K. Miller, JOM, 66 (2014) 747-755.

[4] F.G. Caballero, H.K.D.H. Bhadeshia, K.J.A. Mawella, D.G. Jones, and P. Brown, Mater. Sci. Technol. 18 (2002) 279-284.

[5] C. Garcia-Mateo, F.G. Caballero,H.K.D.H. Bhadeshia, ISIJ Int. 43 (2003) 1238-1243.

[6]. H.K.D.H. Bhadeshia, Mater. Sci. Technol. 21 (2005) 1293-1302.

[7] C. Garcia-Mateo, T. Sourmail, F.G. Caballero, V. Smanio, M. Kuntz, C. Ziegler, A.

Leiro, E. Vuorinen, R. Elvira, and T. Teeri, Mater. Sci. Technol. $30 / 9$ (2014) 1071-1078.

[8] C. García-Mateo, H.K.D.H. Bhadeshia, Mat. Sci. Eng A, A378 (2004) 289-292.

[9] R.F. Hehemann, K. R. Kinsman, H. I. Aaronson, Metall Trans. 3 (1972) 1077-1094.

[10] P. H. Wright, T.L. Harrington, W. A. Szilva, T.R. White, TMS (1987) 541-565.

[11] M. Imagumbai in H.C. Lee (Eds.), Ultrafine grained HSLA steel made from bainitic heterogeneity. In: $3^{\text {rd }}$ Int. Conf. on Advanced Structural Steel. Korean Institute of Metal and Materials, Seoul, Republic of Korea 2005, pp.156-161.

[12] D. Myszka, L. Cybula and A. Wievzorek, Arch. Metall. Mater. 59 (2014) 1170-1179.

[13] D.B. Spencer, R.Mehrabian, M.Flemings, Metall.Mater.Trans.A. 3 (1972) 1925-1932.

[14] G. Hirt and R. Kopp, Thixoforming- Semi-solid Metal Processing, Weinheim

WILEYVCH, Verlag GmbH \& Co. KGaA, 2009.

[15] Z. Fan, Int Mater Rev 47/2 (2002) 49-85.

[16] Kirkwood D.H., Semi-solid Processing of Alloys, Springer Series in Materials Science, vol. 124, London, 2010.

[17] B. Hallstedt, E. Balitchev, H. Shimahara, D. Neuschütz ISIJ Int 46 (2006) 1852-1859.

[18] M. Z. Omar, E. J. Palmiere, A.A. Howe, H.V. Atkinson, P. Kapranos, Mater Sci Eng A 395 (2005) 53-61.

[19] W. Püttgen, W. Bleck, G. Hirt, Adv Eng Mater 9/4 (2007) 231-45.

[20] F. Knauf, I. Seidl, G. Hirt, Solid State Phenom 116-117 (2006) 464-471.

[21] D. I. Uhlenhaut, J. Kradolfer, P. J. Uggowitzer, Acta Mater. 54 (2006) 2727-2734.

[22] Ł. Rogal, J. Dutkiewicz, Metall Mater Trans A, 43A (2012) 5009-5018.

[23] Ł. Rogal, J. Dutkiewicz, Mater Charact. 68 (2012) 123-130.

[24] Ł. Rogal, J. Dutkiewicz, T. Czeppe, J. Bonarski, B. Olszowska-Sobieraj, Trans

Nonferrous Met Soc. China, 20 (2010) 1033-1036.

[25] Ł. Rogal, G. Korpala, J. Dutkiewicz, Mater. Sci. Eng. A,624 (2015) 291-299.

[26] W. Püttgen, B. Hallstedt, W. Bleck, J.F. Loffler, P.J. Uggowitzer, Acta Mater. 55/19 (2007) 6553-6560.

[27] W. Püttgen, B. Hallstedt, W. Bleck, P.J. Uggowitzer, Acta Mater. 55/3 (2007) 10331042 .

[28] H. K. D. H. Bhadeshia, Bainite in Steels (3rd edition), Theory and Practice, Maney Publishing, United Kingdom 2015.

[29] I. Lonardelli, M. Bortolotti, W. van Beek, L. Girardini, M. Zadra, H. K. D. H. Bhadeshia, Mat. Sci. Eng A, 555 (2012)139-147.

[30] E. Vuorinen, J. Vang, M. Carradot, P. Johansson, E. Navara, Mater. Sci. Forum, 782 (2014) 480-486.

[31] F. G. Caballero, C. Garcia-Mateo, M. K. Miller, JOM 66 (2014) 747-755.

[32] H. Y. Li, and X. J. Jin, Journal of Shanghai Jiaotong University 44 (2010) 613-615.

[33] M. J. Peet, H. K. D. H. Bhadeshia, Metall. Mater. Trans. A, $42 / 11$ (2011) 3344-3348.

[34] I. Gurrappa, C.V. Krishna Reddy, J. Mater. Process. Technol. 182 (2007) 195-201.

[35] M. Umemoto, Y. Todaka, K. Tsuchiya, Mater. Trans., 44/7 (2003) 1488-1493.

[36] J. Millan, D. Ponge, J. Neugebauer, D. Raabe, Nanoscale Transformations in Steels, Workshop, Max Planck Institut, Germany 2013.

[37] H.K.D.H. Bhadeshia, D.V. Edmunds, Metal Science 14 (1980) 41-49. 
[38] H.K.D.H. Bhadeshia and D.V. Edmonds, Acta Metallurgica 28 (1980) 1265-1273.

[39] W. Solano-Alvarez and H. K. D. H. Bhadeshia, White-Etching Matter in Bearing Steel. Part II: Distinguishing Cause and Effect in Bearing Steel Failure. Metallurgical and Materials Transactions A, 45:11 (2014) 4916-4931.

[40] D. J. Dyson and B. Holmes, Effect of alloying additions on the lattice parameter austenite, Journal of the Iron and Steel Institute 208 (1970) 469-474.

[41] E. Honda and Z. Nishiyama, On the nature of the tetragonal and cubic martensites, Science Reports of Tohoku Imperial University 21 (1932) 299-331.

[42] P.A. Christensenand, A. Hamnett, Techniques and mechanisms in electrochemistry, Kluwer Academic Publishers, Chapman \& Hall, London 1994.

[43] A. J. Bard, L. R. Faulkner, Electrochemical Methods: Fundamentals and Applications, John Wiley \& Sons, Inc. New York, 2001.

[44] D.H., Kirkwood: 'Semi-solid Processing of Alloys, Springer Series in Materials Science, 124 (2010) 1-30.

[45] H.V. Atkinson, K. Burke, G. Vaneetveld, Mater. Sci. Eng., A, 490/1-2 (2008) 266-276.

[46] Ł. Rogal, J. Dutkiewicz, H.V. Atkinson, L. Lityńska-Dobrzyńska, T. Czeppe, M.

Modigell,_Mater. Sci. Eng., A, 580 (2012) 362-373

[47] Ł. Rogal, J. Dutkiewicz, Mater. Sci. Eng., A, 603 (2014) 93-97.

[48] W. Solano-Alvarez, H.F.G. Abreu, M.R. da Silva, M.J. Peet, J Magn Magn Mater 378 (2015) 200-205.

[49] Y. Ohmori, H. Ohtani, and T. Kunitake, Trans ISIJ, 11 (1971) 250-259.

[50] C.M. Amey, H.Huang, P.E.J.Rivera-Díaz-del-Castillo, Mater. Des. 35 (2012) 66-71.

[51] A.T.W. Barrow, P.E.J. Rivera-D1'az-del-Castillo, Acta. Mater., 59 (2011) 7155-7167.

[52] H.K.D.H. Bhadeshia, Microstructure Bainite in Steel-Transformation and Properties, second edition, University Press, Cambridge 2001.

[53] F. G. Caballero, H. K. D. H. Bhadeshia, K. J. A. Mawella, D. G. Jones, and P. Brown, Mater. Sci. Technol. 18 (2002) 279-285.

[54] H.K.D.H. Bhadeshia, Steel for bearing, Progress in Material Science 57 (2012) 268-435.

[55] W. Song, U. Prahl, W. Bleck, K. Mukherjee, Supplemental Proceedings: Materials

Fabrication, Properties, Characterization, and Modeling, 2 (2011) 417-427.

[56] H.V. Atkinson, Modelling of Semi-Solid Processing, Shaker Verlang, Aachen 2008.

[57] F.G. Caballero and H.K.D.H Bhadeshia, Curr. Opin. Solid State Mater. Sci., 8 (2004) 251-257.

[58] F.G. Caballero, M.K. Miller, C. Garcia-Mateo, Acta Mater. 58 (2010) 2338-2343.

[59] F.G. Caballero, M.K. Miller, S.S. Babu, C. Garcia-Mateo, Acta Mater. 55 (2007) 381390.

[60] W. Luty, Metaloznawstwo i obróbka cieplna stali łożyskowych, Wydawnictwa Naukowo-Techniczne, Warszawa 1980.

[61] M. Peet, PhD thesis: 'Transformation and Tempering of Low Temperature Bainite', University of Cambridge, 2010.

[62] C. H. Young and H. K. D. H. Bhadeshia, Mater. Sci. Technol. 10 (1994) 209-214.

[63] Y.F. Shen, X.X. Li, X. Sun, Y.D. Wang, L. Zuo, Mater. Sci. Eng. A 552 (2012) 514-522.

[64] A. Saeed-Akbari, L. Mosecker, A. Schwedt, W. Bleck, Metall. Mater. Trans. A, 43A

(2012) 1688-1704.

[65] W.R. Oso'rio, L.C. Peixoto, L.R. Garcia and A.Garcia, Mater Corros 60/10 (2009) 804812.

[66] A. Pfennig, P. Zastrow, A. Kranzmann, Int. J Greenh. Gas Con.15 (2013) 213-224.

[67] Ł. Rogal, J. Dutkiewicz, Z. Szklarz, H. Krawiec, M. Kot, S. Zimowski, Mater. Charact. 88 (2014) 100-110. 
[68] O. Kazum, M. Bobby Kannan, H. Beladi, I.B. Timokhina, P.D. Hodgson, S. Khoddam, Mater. Design. 54 (2014) 67-71.

\section{Tables}

Table 1. Chemical composition of super bainite steel in wt.\%.

Table 2. Results of UCS, YS and $\mathrm{a}_{\mathrm{c}}$ for SB steel after directly cooling to water and $100^{\circ} \mathrm{C}$ oil and isothermal treatment (present study) and another grade of steel is presented for comparison $[25,50]$.

\section{Figures Caption}

Figure 1. DSC heating flow and liquid fraction curves for super bainite steel.

Figure 2. Microstructure of SB steel a) annealed and hot rolled, b) heated to $1430^{\circ} \mathrm{C}$ and cooled in water, c) upset to $50 \%$ in height, d) upset and heated to $1430^{\circ} \mathrm{C}$, cooled in water.

Figure 3. Microstructures obtained using optical microscopy and SEM of upset SB steel heated to $1430^{\circ} \mathrm{C}$ and cooled to the bainitic transformation temperature range; a, b) $240^{\circ} \mathrm{C} / 5 \mathrm{~h}$, c, d ) $\left.270^{\circ} \mathrm{C} / 5 \mathrm{~h}, \mathrm{e}, \mathrm{f}\right) 300^{\circ} \mathrm{C} / 5 \mathrm{~h}$.

Figure 4. TEM microstructure of SB steel after isothermal treatment at $240^{\circ} \mathrm{C} / 5 \mathrm{~h}$ of an area of globular grains a, b) BF micrograph taken of the same place but at different Bragg conditions with SAEDP from the selected area, c) BF with SAEDP of another region; showing a clear fine martensitic structure, d) fine strings of $\gamma$ phase at an angle of $45^{\circ}$ to primary bands and $\alpha_{\mathrm{b}}$ ferrite.

Figure 5. TEM microstructure of SB steel after isothermal treatment at $270^{\circ} \mathrm{C}$ of an area of globular grains a) BF micrograph with bainitic structure and SAEDPs from the area marked with circles $(b, c)$.

Figure 6. TEM microstructure of SB steel after isothermal treatment at $270^{\circ} \mathrm{C}$ of another globular grain area; bright field with diffraction pattern shows reflections from martensite and a transitional carbide.

Figure 7. TEM microstructure of SB steel after isothermal treatment at $300^{\circ} \mathrm{C}$ from the area of globular grains a, b) BF micrograph taken of the same place but at different Bragg conditions with SAEDP of the selected area $(c, d)$

Figure 8. TEM microstructure of SB steel after isothermal treatment at $300^{\circ} \mathrm{C}$ from another area of globular grains BF with SAEDP; visible fine martensitic structure.

Figure 9. TEM microstructure of SB steel after isothermal treatment at $300^{\circ} \mathrm{C}$ from an area of globular grains a) BF micrograph with bainitic structure and SAEDP from the indicated areas $(b, c)$. 
Figure 10. Compression curves of SB steel after cooling from $1430^{\circ} \mathrm{C}$ to water and $100^{\circ} \mathrm{C}$ oil followed by isothermal treatment at $240^{\circ} \mathrm{C}, 270^{\circ} \mathrm{C}, 300^{\circ} \mathrm{C}$ and held $5 \mathrm{~h}$ (present study results). In addition, values of compression strength and compression strain after isothermal treatment of $100 \mathrm{Cr} 6$ steel cooled from $1425^{\circ} \mathrm{C}$ to 135,235 and $335^{\circ} \mathrm{C} / 5 \mathrm{~h}$ ) reported in an earlier study [25], and SB steel after hot rolling and typical heat treatment [50] were added.

Figure 11. Results of hardness measurements for three temperatures of isothermal treatment: 240, 270 and $300^{\circ} \mathrm{C} / 5 \mathrm{~h} \mathrm{SB}$ steel - bright columns correspond to materials after direct treatments, while dark columns correspond to samples deformed at room temperature (up to stress when cracking starts).

Figure 12. X-ray diffraction patterns of SB steel treated at $1425^{\circ} \mathrm{C} / 240^{\circ} \mathrm{C} / 5 \mathrm{~h}$, a) nondeformed and b) compressed at 6.6 GPa.

Figure 13. The microstructures of $\mathrm{SB}$ steel after treatment at $270^{\circ} \mathrm{C} / 5 \mathrm{~h}$ obtained from the area parallel to the axis of the applied force after $4200 \mathrm{MPa}$ stress obtained using a) optical microscopy ,b) SEM-BSE, c) TEM-BF.

Figure 14 (a) Corrosion potential (OCP) measurements and (b) polarization curves (LSV) obtained for SB steel $\mathrm{HR}\left(1000^{\circ} \mathrm{C} / 240^{\circ} \mathrm{C} / 20 \mathrm{~h}\right.$; solid lines $)$ - and SB steel $\left(1430^{\circ} \mathrm{C} / 240^{\circ} \mathrm{C} / 5 \mathrm{~h}\right.$; dot lines) in $0.1 \mathrm{M} \mathrm{NaCl}$ water solution. 


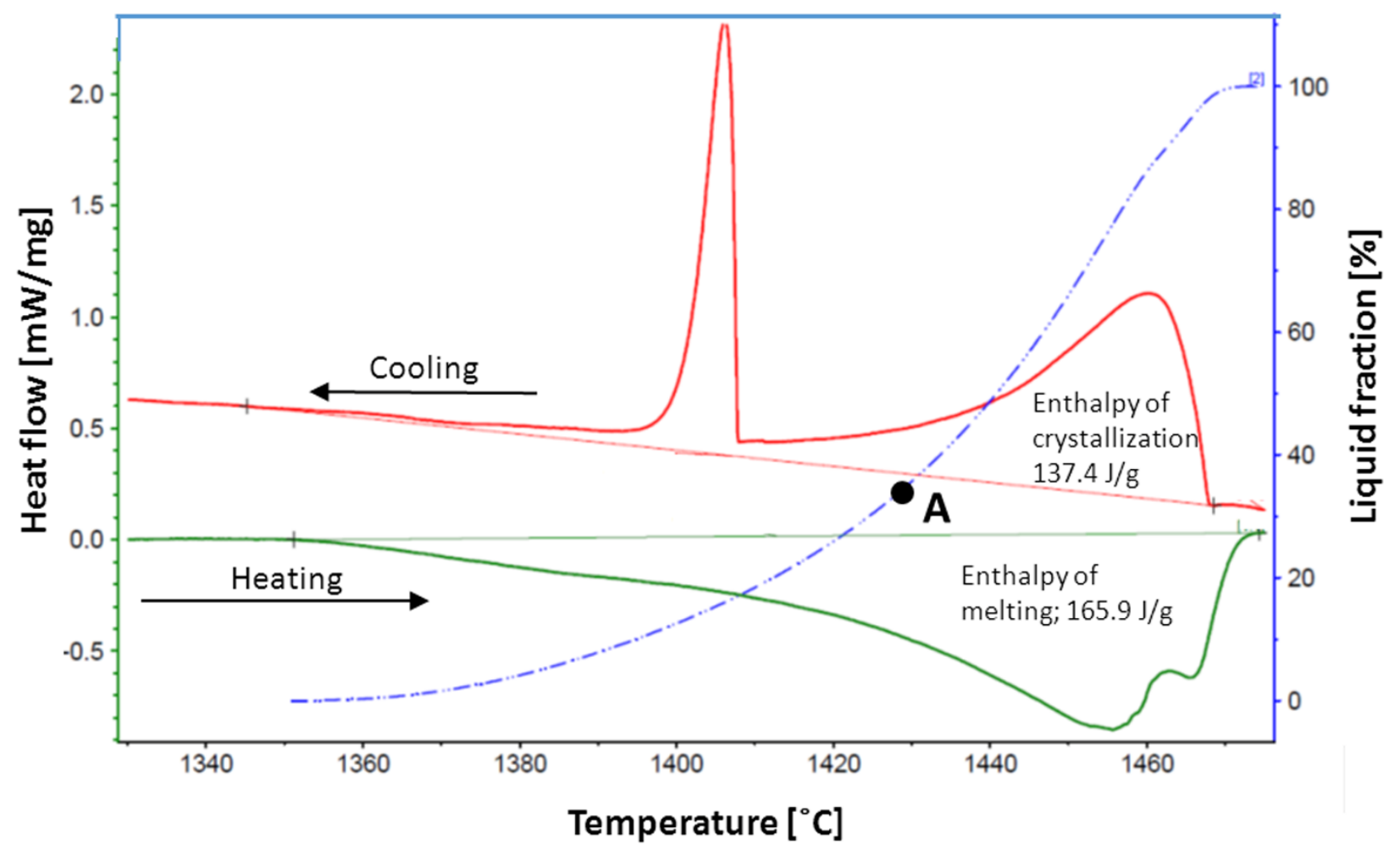

Figure 1. DSC heating flow and liquid fraction curves for super bainite steel. 

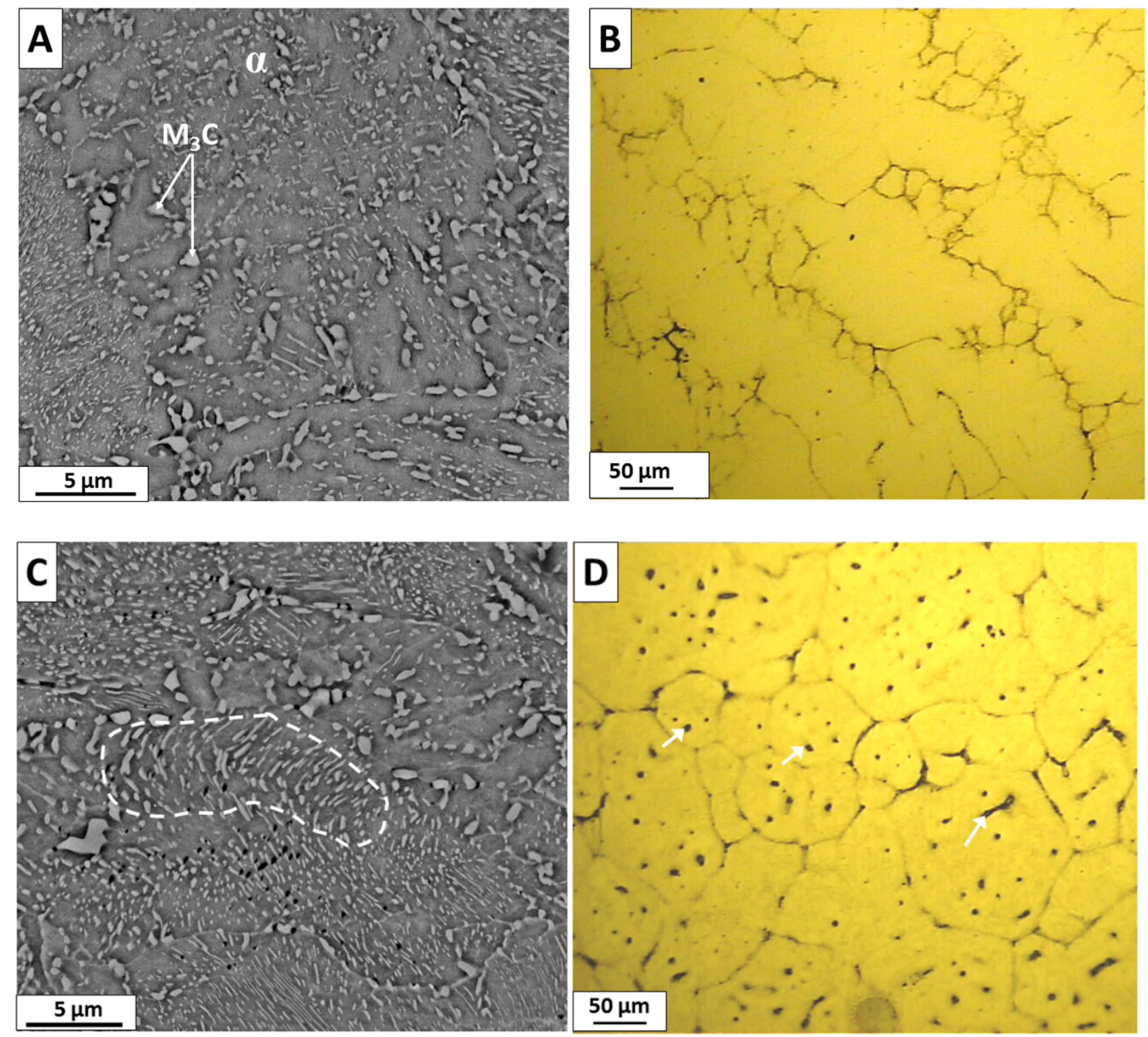

Figure 2. Microstructure of SB steel a) annealed and hot rolled, b) heated to $1430^{\circ} \mathrm{C}$ and cooled in water, c) upset to $50 \%$ in height, d) upset and heated to $1430^{\circ} \mathrm{C}$, cooled in water. 

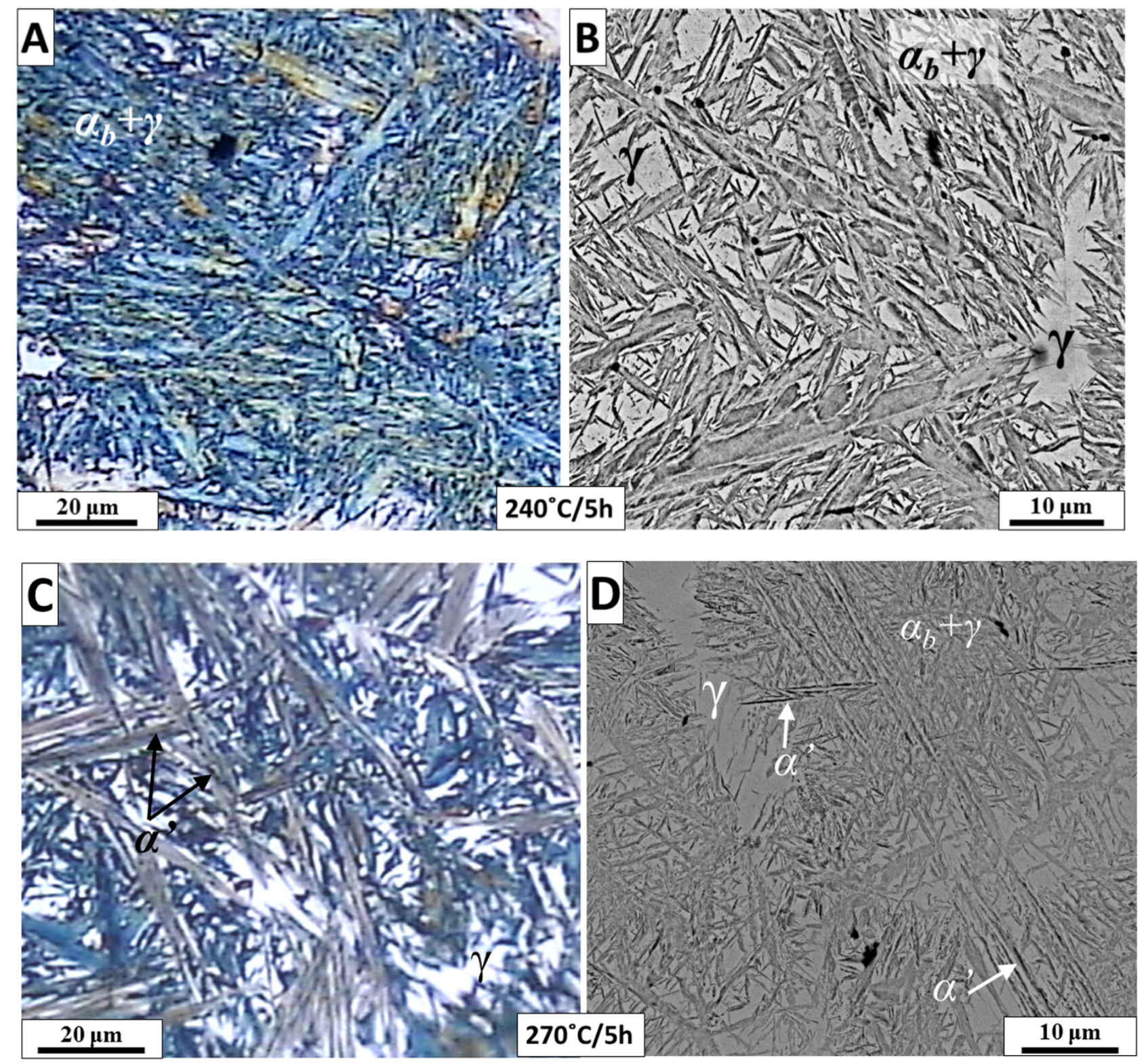

Figure 3. Microstructures obtained using optical microscopy and SEM of upset SB steel heated to $1430^{\circ} \mathrm{C}$ and cooled to the bainitic transformation temperature range; a, b) $240^{\circ} \mathrm{C} / 5 \mathrm{~h}$, c, d ) $270^{\circ} \mathrm{C} / 5 \mathrm{~h}$. 


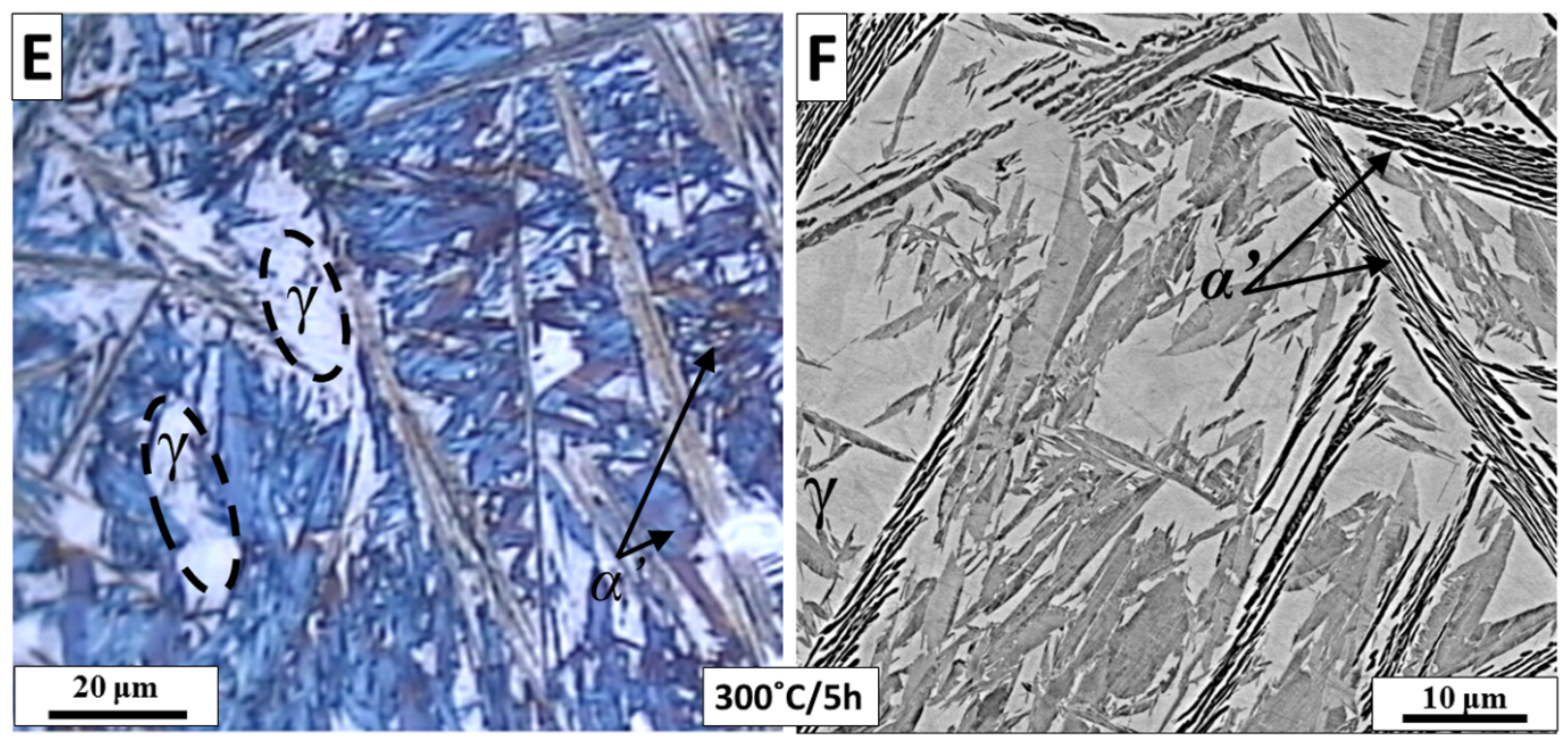

Figure 3. Microstructures obtained using optical microscopy and SEM of upset SB steel heated to $1430^{\circ} \mathrm{C}$ and cooled to the bainitic transformation temperature range; e, f) $300^{\circ} \mathrm{C} / 5 \mathrm{~h}$.
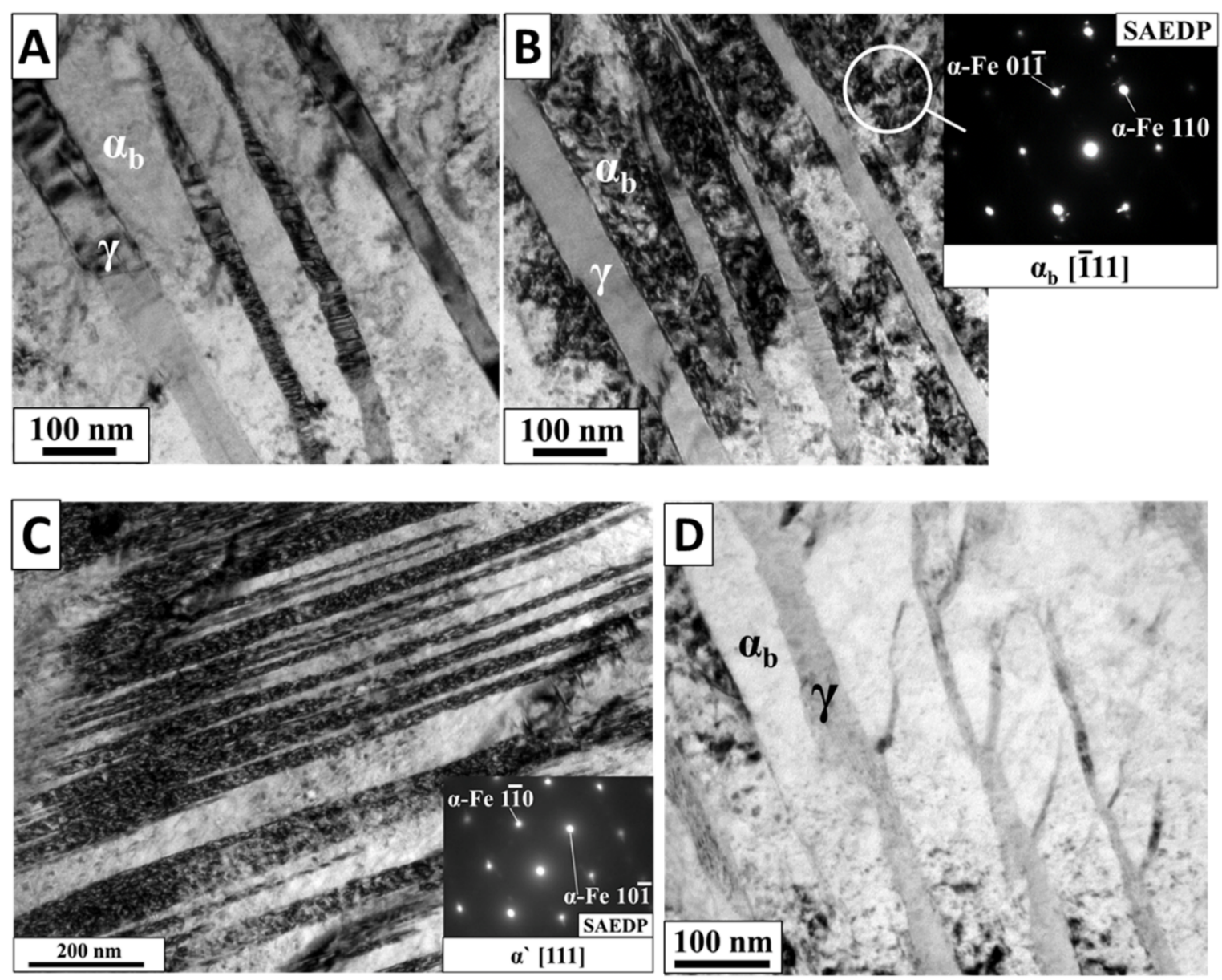

Figure 4. TEM microstructure of SB steel after isothermal treatment at $240^{\circ} \mathrm{C} / 5 \mathrm{~h}$ of an area of globular grains a, b) BF micrograph taken of the same place but at different Bragg conditions with SAEDP from the selected area, c) BF with SAEDP of another region; 
showing a clear fine martensitic structure, d) fine strings of $\gamma$ phase at an angle of $45^{\circ}$ to primary bands and $\alpha_{b}$ ferrite.

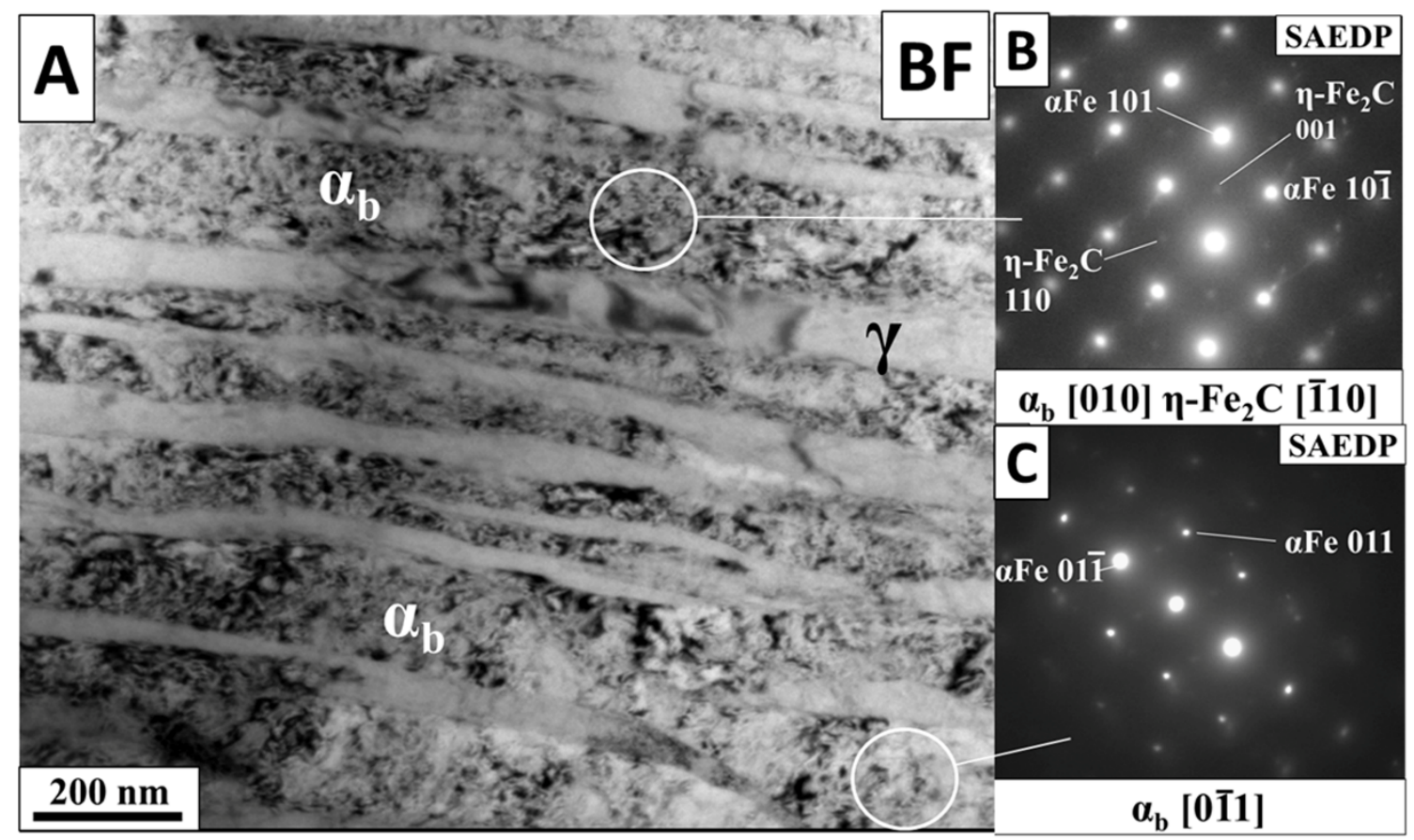

Figure 5. TEM microstructure of SB steel after isothermal treatment at $270^{\circ} \mathrm{C}$ of an area of globular grains a) BF micrograph with bainitic structure and SAEDPs from the area marked with circles $(b, c)$.

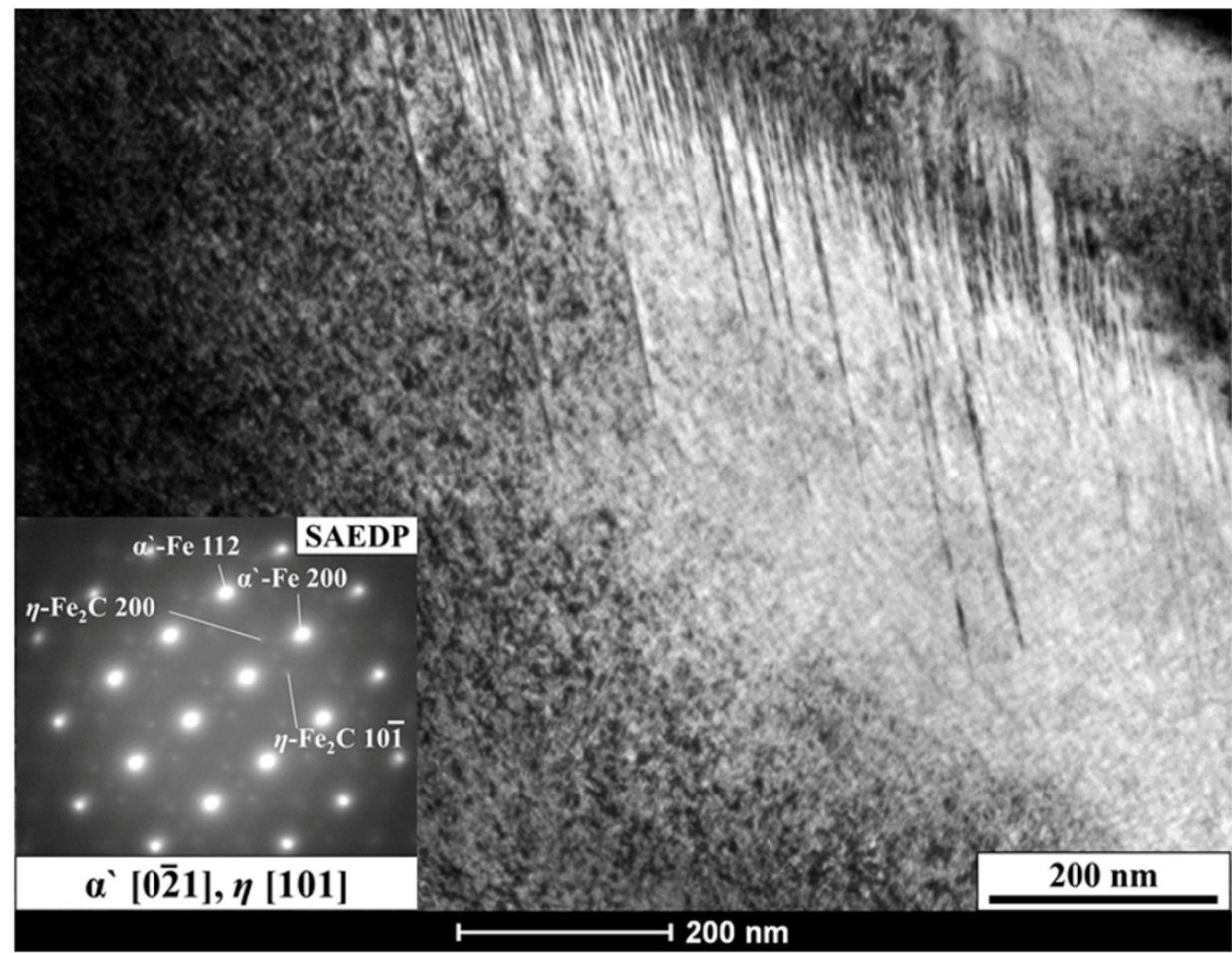


Figure 6. TEM microstructure of SB steel after isothermal treatment at $270^{\circ} \mathrm{C}$ of another globular grain area; bright field with diffraction pattern shows reflections from martensite and a transitional carbide.
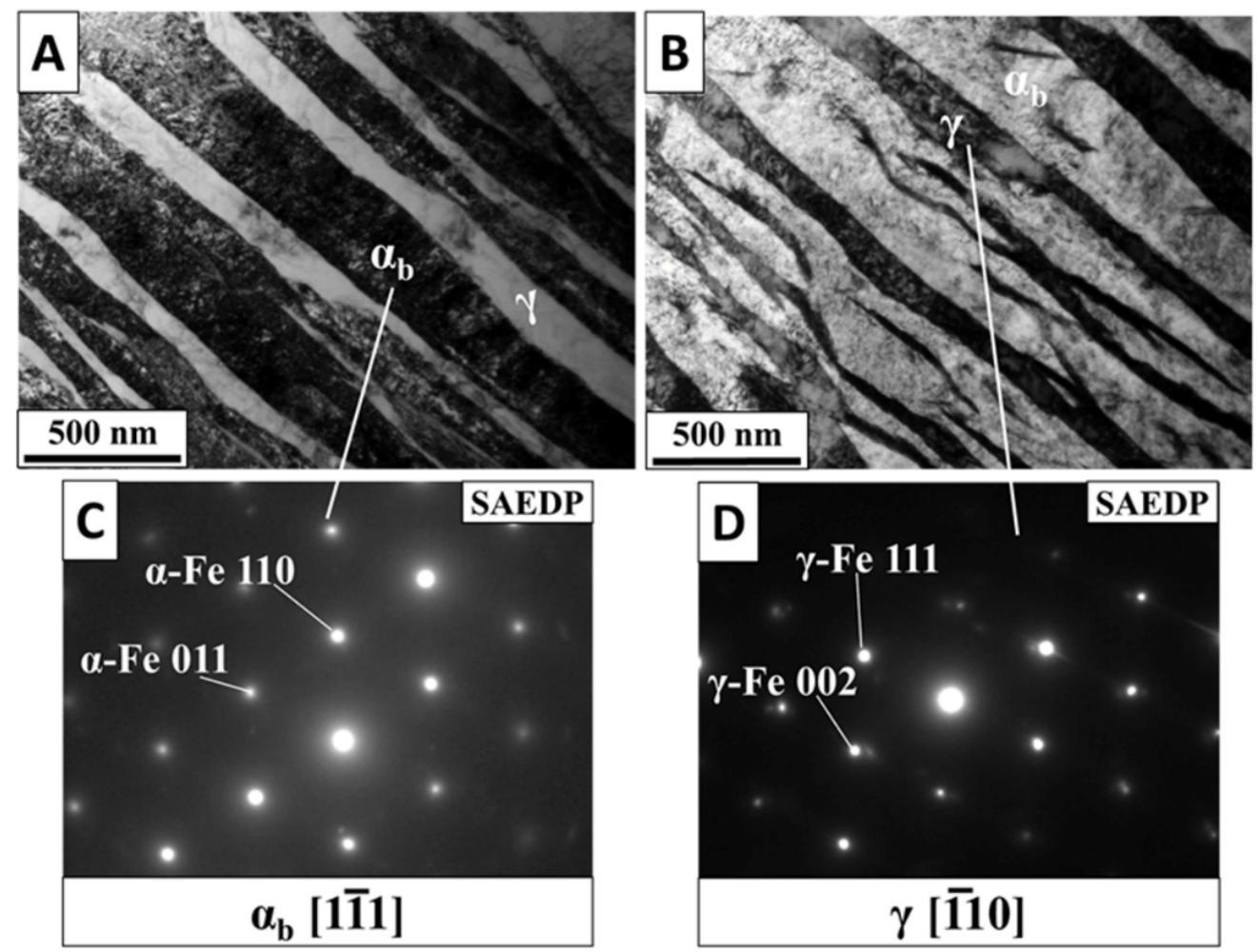

Figure 7. TEM microstructure of SB steel after isothermal treatment at $300^{\circ} \mathrm{C}$ from the area of globular grains a, b) BF micrograph taken of the same place but at different Bragg conditions with SAEDP of the selected area $(c, d)$ 


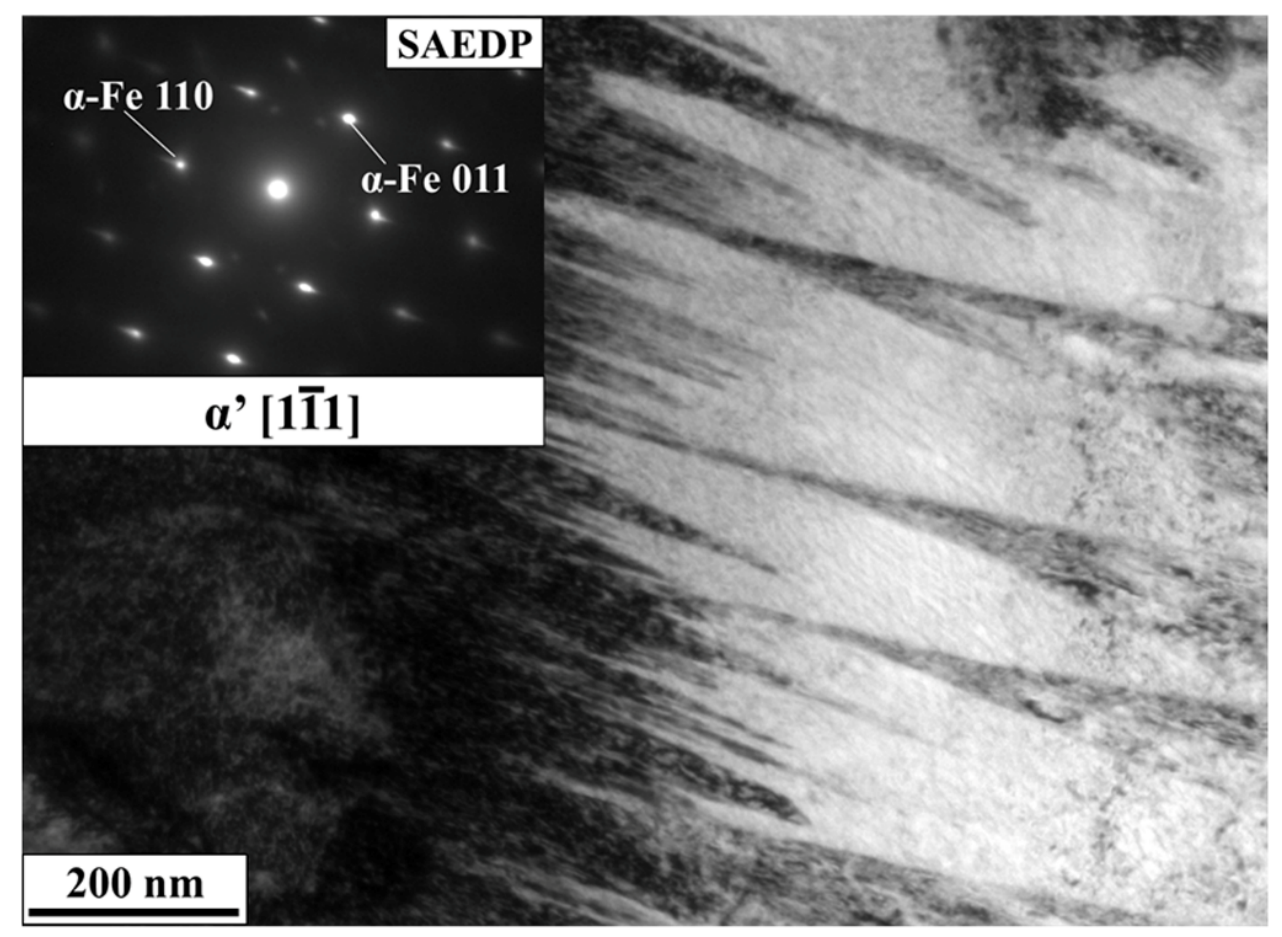

Figure 8. TEM microstructure of SB steel after isothermal treatment at $300^{\circ} \mathrm{C}$ from another area of globular grains BF with SAEDP; visible fine martensitic structure.

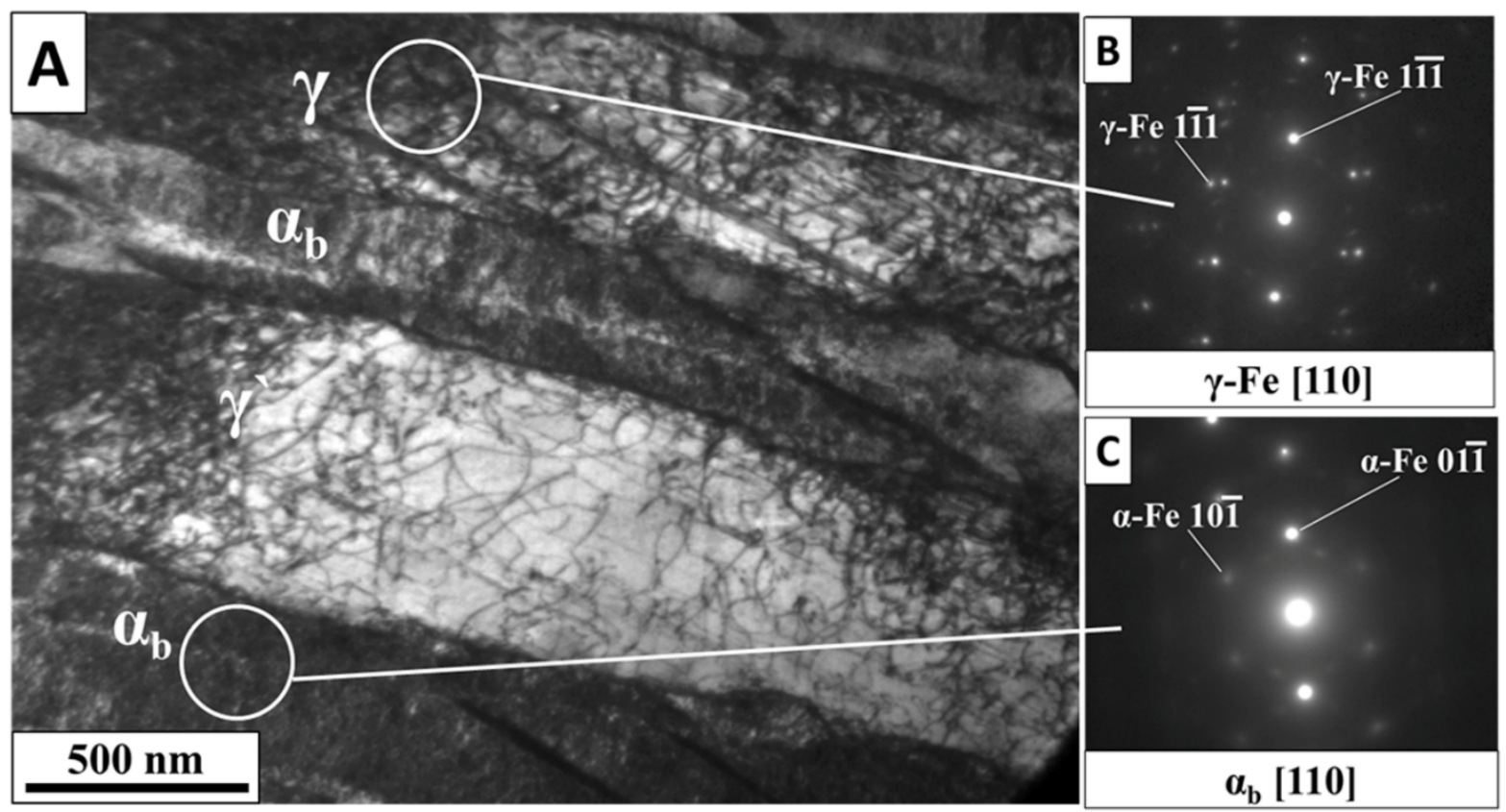

Figure 9. TEM microstructure of SB steel after isothermal treatment at $300^{\circ} \mathrm{C}$ from an area of globular grains a) BF micrograph with bainitic structure and SAEDP from the indicated areas $(b, c)$. 


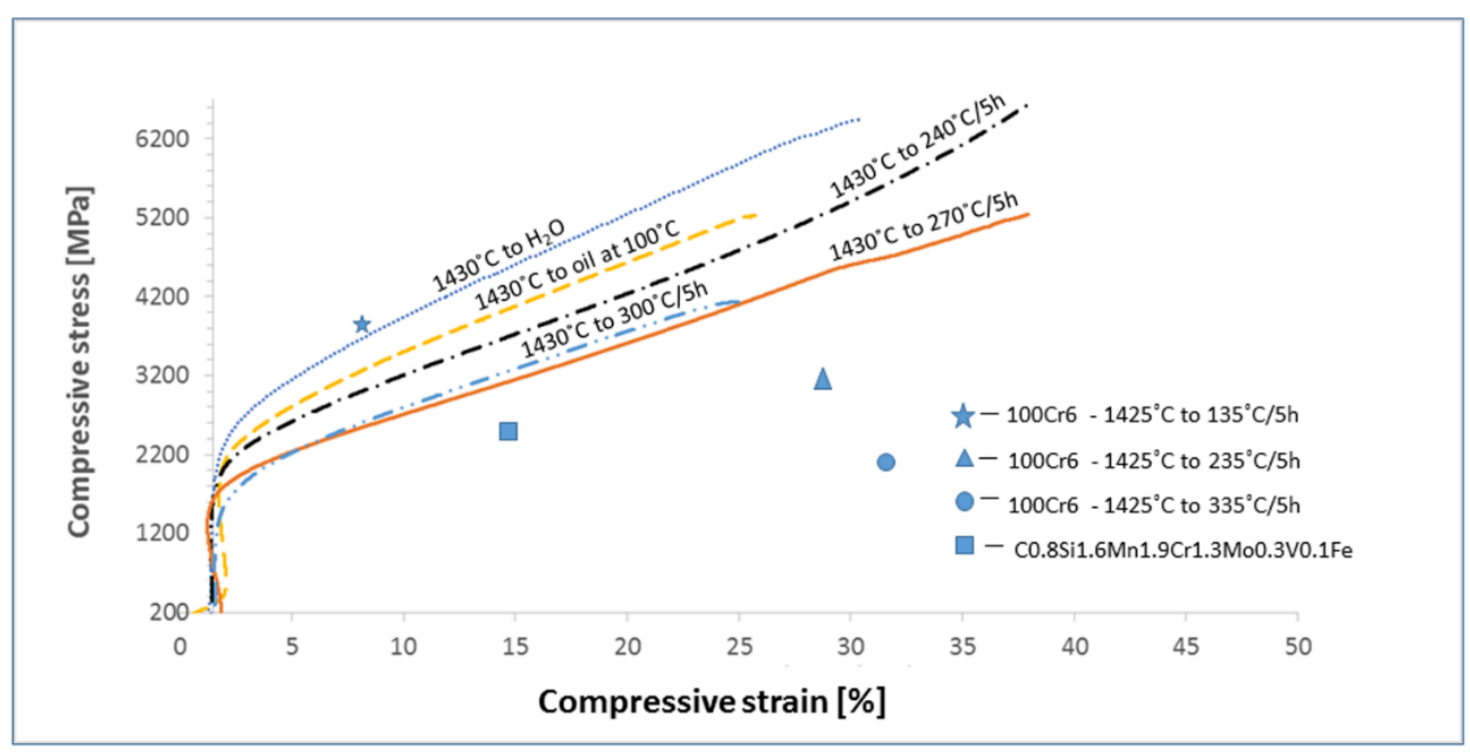

Figure 10. Compression curves of SB steel after cooling from $1430^{\circ} \mathrm{C}$ to water and $100^{\circ} \mathrm{C}$ oil followed by isothermal treatment at $240^{\circ} \mathrm{C}, 270^{\circ} \mathrm{C}, 300^{\circ} \mathrm{C}$ and held $5 \mathrm{~h}$ (present study results). In addition, values of compression strength and compression strain after isothermal treatment of $100 \mathrm{Cr} 6$ steel cooled from $1425^{\circ} \mathrm{C}$ to 135,235 and $335^{\circ} \mathrm{C} / 5 \mathrm{~h}$ ) reported in an earlier study [25], and SB steel after hot rolling and typical heat treatment [50] were added.

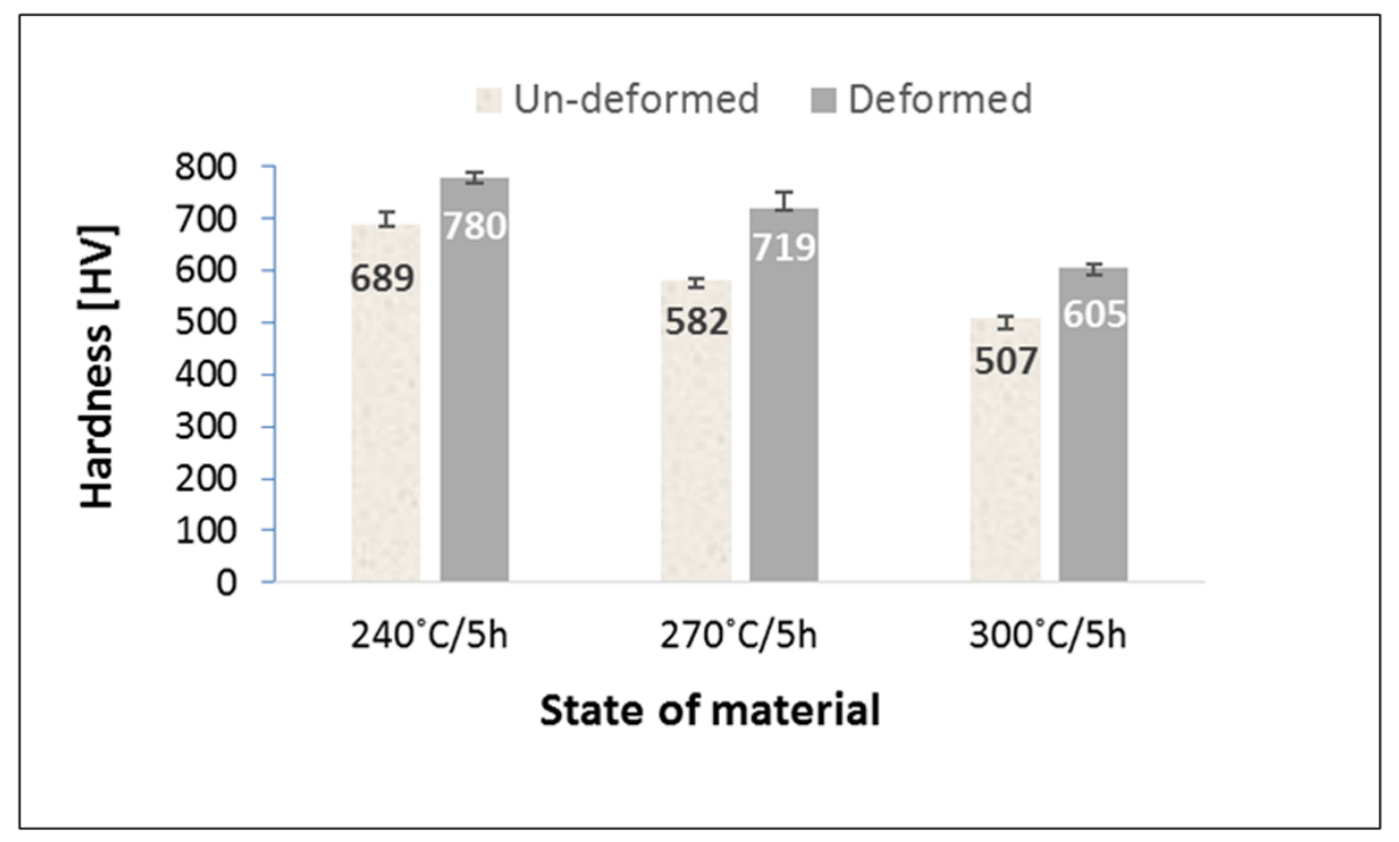

Figure 11. Results of hardness measurements for three temperatures of isothermal treatment: 240, 270 and $300^{\circ} \mathrm{C} / 5 \mathrm{~h} \mathrm{SB}$ steel - bright columns correspond to materials after direct treatments, while dark columns correspond to samples deformed at room temperature (up to stress when cracking starts). 


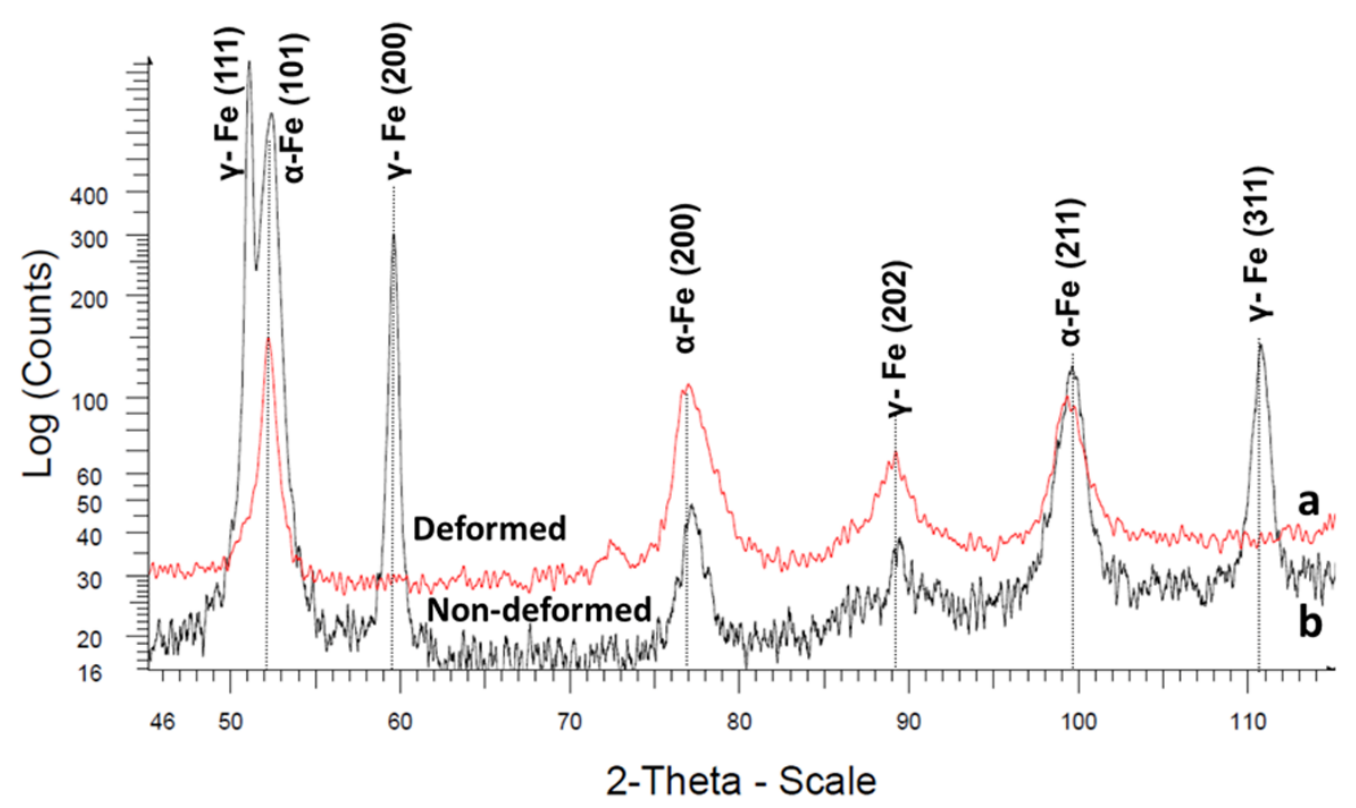

Figure 12. X-ray diffraction patterns of SB steel treated at $1425^{\circ} \mathrm{C} / 240^{\circ} \mathrm{C} / 5 \mathrm{~h}$, a) nondeformed and b) compressed at $6.6 \mathrm{GPa}$.
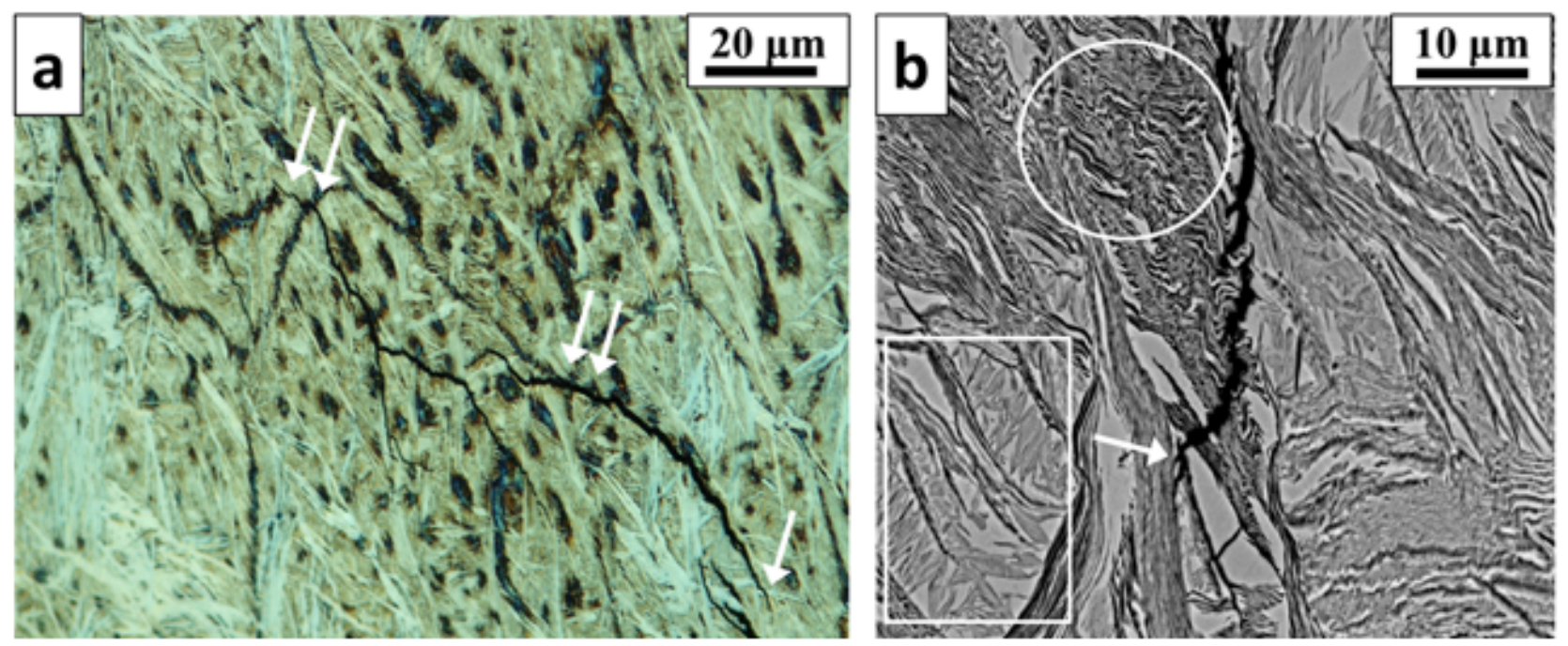


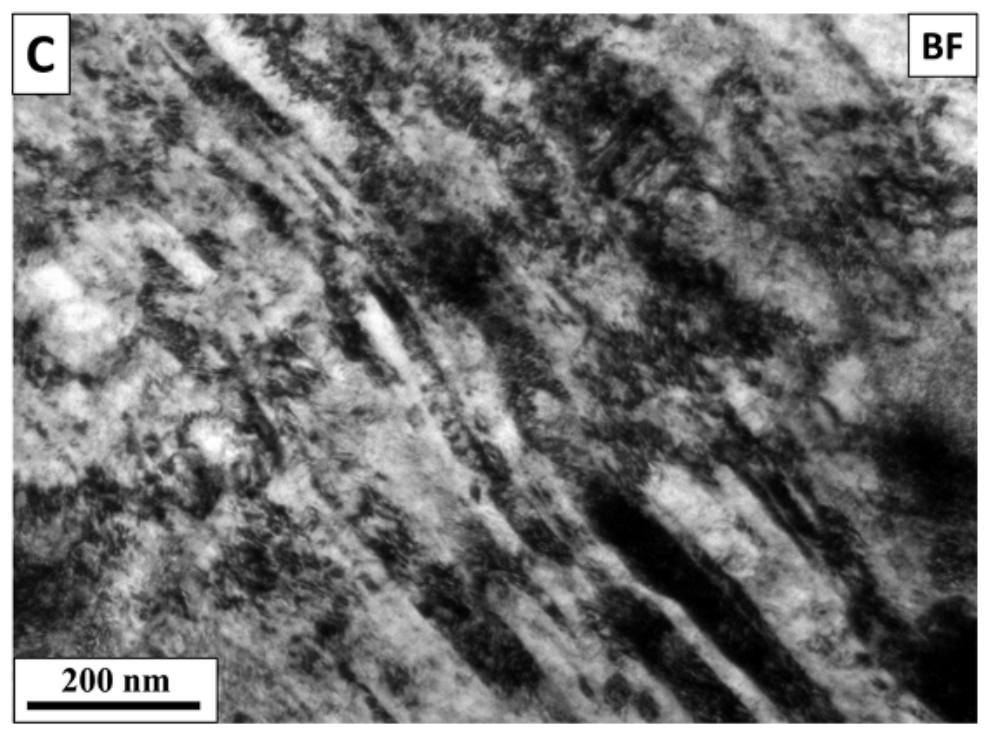

Figure 13. The microstructures of SB steel after treatment at $270^{\circ} \mathrm{C} / 5 \mathrm{~h}$ obtained from the area parallel to the axis of the applied force after $4200 \mathrm{MPa}$ stress obtained using a) optical microscopy ,b) SEM-BSE, c) TEM-BF. 

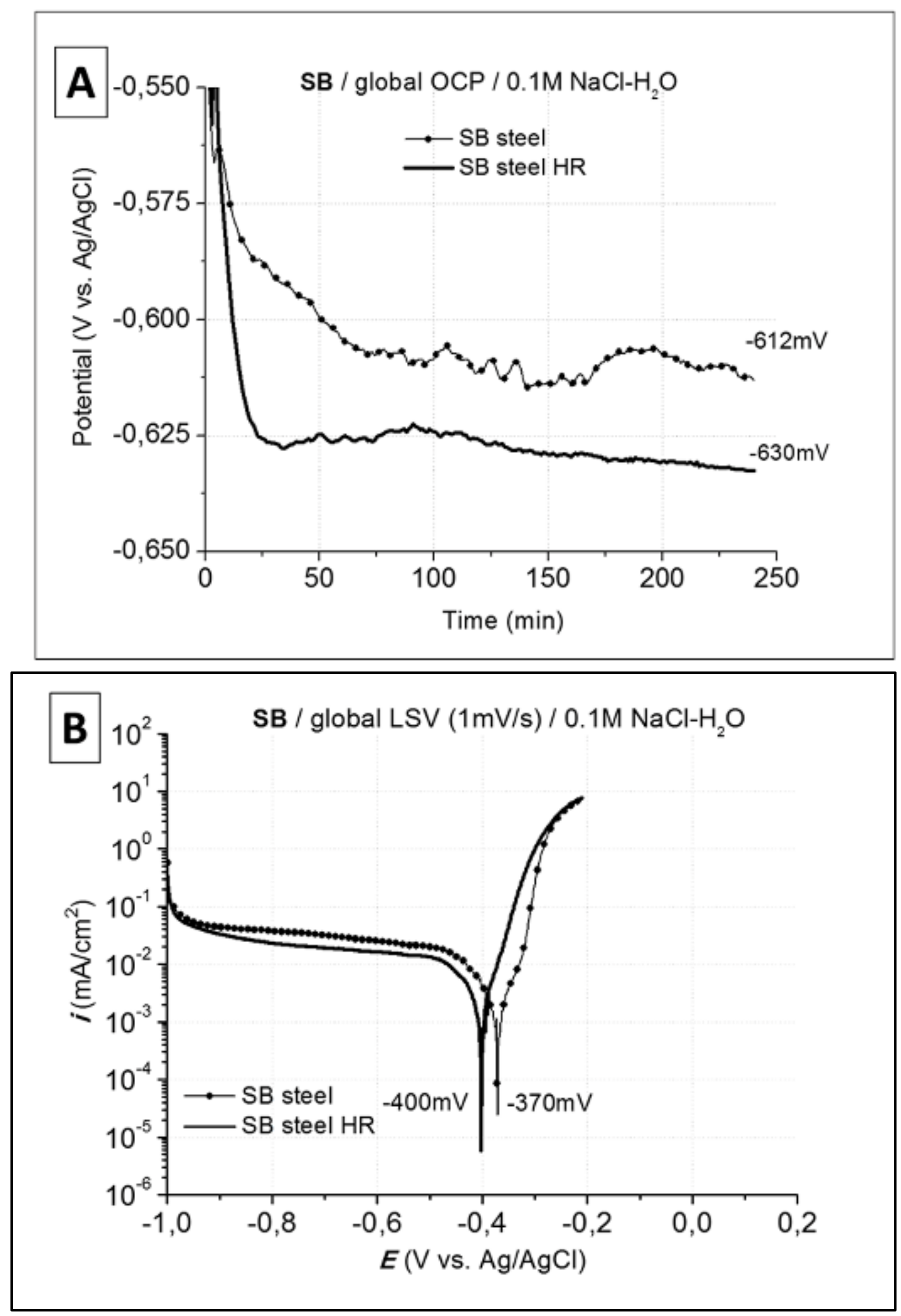

Figure 14 (a) Corrosion potential (OCP) measurements and (b) polarization curves (LSV) obtained for SB steel $\mathrm{HR}\left(1000^{\circ} \mathrm{C} / 240^{\circ} \mathrm{C} / 20 \mathrm{~h}\right.$; solid lines $)$ - and SB steel $\left(1430^{\circ} \mathrm{C} / 240^{\circ} \mathrm{C} / 5 \mathrm{~h}\right.$; dot lines) in $0.1 \mathrm{M} \mathrm{NaCl}$ water solution. 
Table 1 Chemical composition of studied steel in $\mathrm{wt} \%$.

\begin{tabular}{|c|c|c|c|c|c|c|c|c|c|}
\hline $\mathrm{C}$ & $\mathrm{Si}$ & $\mathrm{Mn}$ & $\mathrm{Mo}$ & $\mathrm{Cr}$ & $\mathrm{Ni}$ & $\mathrm{Al}$ & $\mathrm{P}$ & $\mathrm{S}$ & $\mathrm{Fe}$ \\
\hline 0.74 & 1.64 & 1.82 & 0.36 & 0,21 & 1.00 & 0.047 & 0,009 & 0,005 & balance \\
\hline
\end{tabular}

Table 2. Results of UCS, YS and $\mathrm{a}_{\mathrm{c}}$ for SB steel after directly cooling to water and $100^{\circ} \mathrm{C}$ oil and isothermal treatment (present study) and another grade of steel is presented for

\begin{tabular}{|c|c|c|c|c|c|}
\hline & Technological state & $\begin{array}{c}\text { Condition of } \\
\text { treatment }\end{array}$ & $\begin{array}{c}\text { UCS } \\
{[\mathrm{MPa}]}\end{array}$ & $\begin{array}{c}\text { YS } \\
{[\mathbf{M P a}]}\end{array}$ & $\begin{array}{c}\mathbf{a}_{\mathbf{C}} \\
{[\%]}\end{array}$ \\
\hline \multirow{5}{*}{ 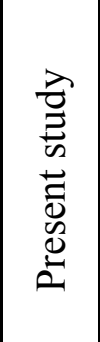 } & \multirow{3}{*}{$\begin{array}{l}\text { Isothermal treatment during cooling } \\
\text { from } 1430^{\circ} \mathrm{C} \text { to: }\end{array}$} & $240^{\circ} \mathrm{C} / 5 \mathrm{~h}$ & 6651 & 1780 & 38 \\
\hline & & $270^{\circ} \mathrm{C} / 5 \mathrm{~h}$ & 5243 & 1370 & 38.5 \\
\hline & & $300^{\circ} \mathrm{C} / 5 \mathrm{~h}$ & 4138 & 1375 & 25 \\
\hline & \multirow{2}{*}{$\begin{array}{c}\text { Directly after cooling from } 1430^{\circ} \mathrm{C} \\
\text { to: }\end{array}$} & water with $20^{\circ} \mathrm{C}$ & 6452 & 2050 & 31 \\
\hline & & oil with $100^{\circ} \mathrm{C}$ & 5223 & 1925 & 27 \\
\hline$\left|\begin{array}{cc}0 \\
\hdashline & 0 \\
2 & n \\
\hdashline & 0\end{array}\right|$ & $\begin{array}{c}\text { Isothermal treatment of } \\
\text { C0.8Si1.6Mn } 1.9 \mathrm{Cr} 1.2 \mathrm{Mo} 0.3 \text { steel } \\
\text { after cooling from } 1000^{\circ} \mathrm{C} / 15 \mathrm{~min} \\
\text { to: }\end{array}$ & $190^{\circ} \mathrm{C} / 2$ weeks & 2400 & 1850 & 15 \\
\hline
\end{tabular}

comparison $[25,50]$. 


\begin{tabular}{|c|c|c|c|c|c|}
\hline & $\begin{array}{c}\text { Isothermal treatment of } 100 \mathrm{Cr} 6 \\
\text { steel after cooling from } 850^{\circ} \mathrm{C} \text { to: }\end{array}$ & $220^{\circ} \mathrm{C} / 5 \mathrm{~h}$ & 3580 & 2050 & 26,5 \\
\hline
\end{tabular}

